\title{
Diastereo- and Enantioselective Syntheses of Trisubstituted Benzopyrans by Cascade Reactions Catalyzed by Monomeric and Polymeric Recoverable Bifunctional Thioureas and Squaramides
}

\author{
José M. Andrés,* Alicia Maestro, María Valle, Isabel Valencia, and Rafael Pedrosa*(i) \\ Instituto CINQUIMA and Departamento de Química Orgánica, Facultad de Ciencias, Universidad de Valladolid, Paseo de Belén 7, \\ 47011 Valladolid, Spain
}

Supporting Information

\begin{abstract}
Vinylphenyl-substituted squaramides have been tested as organocatalysts for the diastereo- and enantioselective synthesis of trisubstituted benzopyrans via an oxa-Michael intramolecular nitro-Michael cascade reaction. Both the enantio- and diastereoselection were good to moderate, depending on the nature of the chiral scaffold in the catalyst. The diastereoselection is better for the most active catalyst because the final products epimerize at C-3 along the time. Supported squaramide sq-9 prepared by copolymerization of sq-4 with styrene and divinylbenzene is also effective in promoting the cascade reaction, and it is recoverable and reusable for five cycles maintaining the activity.
\end{abstract}

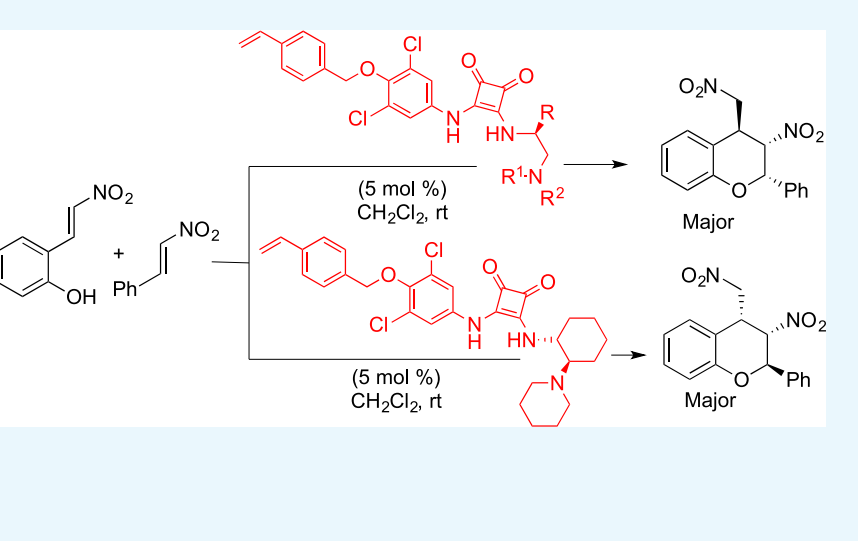

\section{INTRODUCTION}

Polysubstituted chromans are common frameworks in natural and synthetic molecules of biological and pharmaceutical interest, ${ }^{1-5}$ and the synthesis of chiral structures related with these compounds has attracted a lot of work. ${ }^{6-14}$ One of the most efficient approaches to these structures consist on the reaction of 2 -substituted vinylphenol derivatives with $\alpha, \beta$ unsaturated electrophiles. The cascade reaction starts with a Michael reaction, followed by cyclization to the final product in one step, and the organocatalyzed stereoselective version has recently received a great attention. Among these approaches, spirochromanes have been obtained by cascade reactions of ortho-hydroxynitrostyrenes ${ }^{12,15}$ or ortho-hydroxyphenyl paraquinone methides ${ }^{16}$ with different electrophiles. Benzopyrans with three contiguous stereocenters have been prepared by the reaction of different nitroalkenes with ortho-hydroxy chalcones, ${ }^{17,18}$ salicylaldimines, ${ }^{19,20}$ and sequential intermolecular-intramolecular Michael addition of nitromethane ${ }^{21}$ or thiols. $^{22}$

The diastereoselective synthesis of dinitro-trisubstituted benzopyrans by cascade oxa-Michael-nitro-Michael reaction of ortho-hydroxynitrostyrene and nitroalkenes was described fifteen years ago, ${ }^{23}$ but only very recently, the enantioselective version of that process has been developed ${ }^{24}$ by using thioureas and squaramides as catalysts in homogeneous conditions.

Immobilization of molecular catalysts provides heterogeneous materials that simplify the recovering from the reaction mixture, and recycling for batch processes ${ }^{25-28}$ or used in flow systems. $^{29-32}$ As a part of our interest in the search for novel heterogeneous enantiopure bifunctional organocatalysts, we have recently prepared polymeric materials by copolymerization of molecular thioureas and squaramides, which are able to promote different stereoselective cascade reactions. ${ }^{33}$ Now, we report on the stereoselective synthesis of trisubstituted benzopyrans by sequential oxa-Michael-nitro-Michael reactions catalyzed by these novel organocatalysts.

\section{RESULTS AND DISCUSSION}

Searching for the best experimental conditions, we started the study taking the reaction of ortho-hydroxynitrostyrene with nitrostyrene as a model reaction in different solvents. Based on our previous results, we used monomeric squaramides as catalysts with a single stereocenter derived from L-tert-leucine (sq-4, sq-5) and L-valine (sq-6, sq-7), which differ in substitution at the basic nitrogen atom. For comparative purposes, squaramide (sq-8), derived from (1R,2R)-1,2cyclohexane diamine, and its homologous thiourea 8 were also tested as catalysts.

In the proposed reactions, four possible diastereoisomers could be formed, but only two of them, which are epimers at C-3, were detected. $(2 S, 3 S, 4 S)$-trisubstituted benzopyran 3aa was obtained as the major stereoisomer and $(2 S, 3 R, 4 S)$-epi-3aa as a minor one when the reaction was catalyzed by squaramides (sq-4-sq-7), prepared from L-valine or L-tert-

Received: September 6, 2018

Accepted: November 27, 2018

Published: December 5, 2018 
Table 1. Evaluation of Catalysts and Solvents

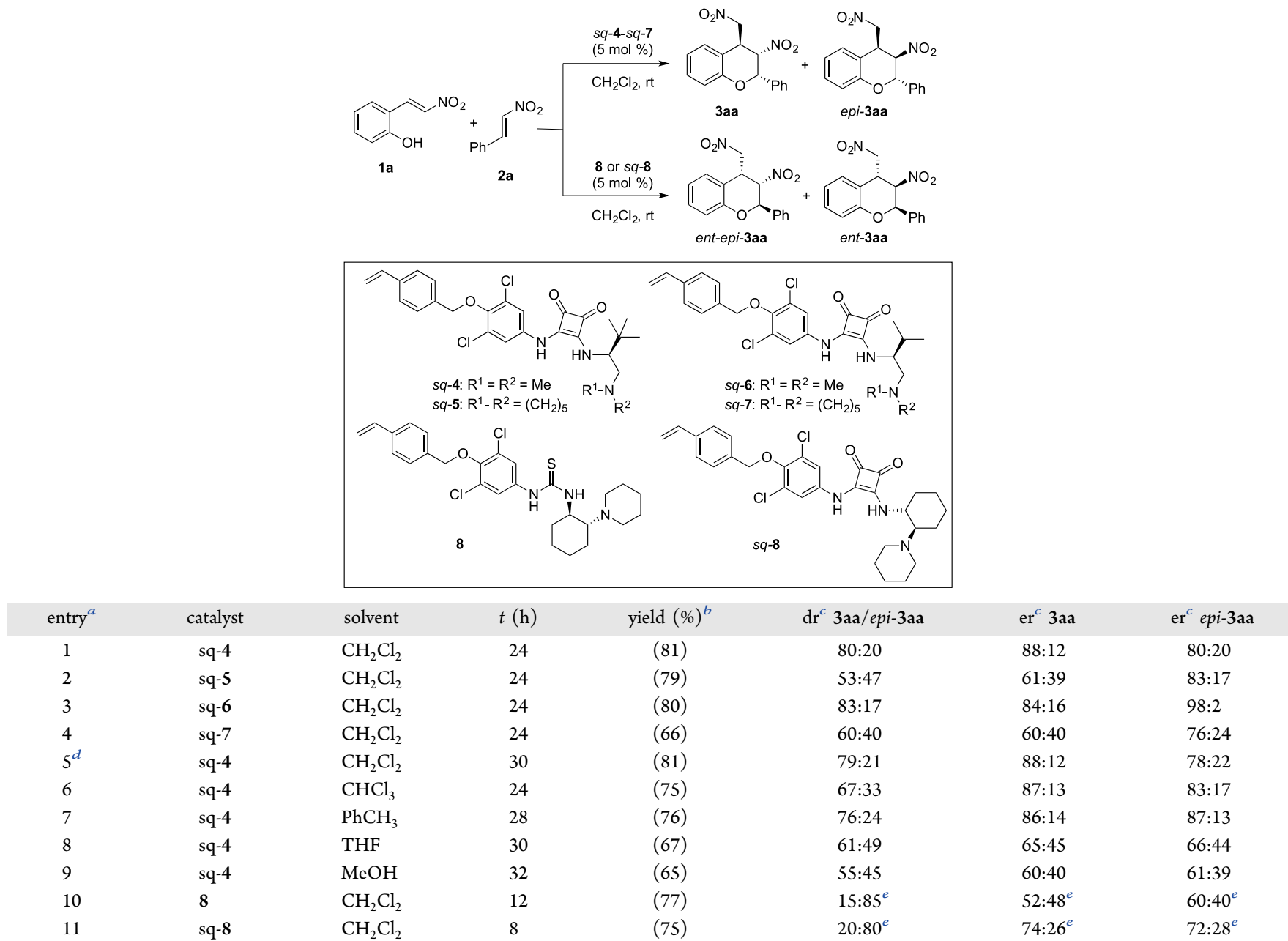

${ }^{a}$ Reactions were performed with $\mathbf{1 a}(0.2 \mathrm{mmol}), \mathbf{2 a}(0.4 \mathrm{mmol})$, and catalyst $(5 \mathrm{~mol} \%)$ in the corresponding solvent $(0.6 \mathrm{~mL})$ at $\mathrm{rt} .{ }^{b}$ Yield after purification by flash chromatography. ${ }^{c}$ Determined by HPLC analysis on a chiral column. ${ }^{d}$ Reaction performed with $2 \%$ of catalyst. ${ }^{e} \mathrm{dr}$ and er correspond to ent-3aa and ent-epi-3aa, respectively.

leucine. As expected, enantiomeric compounds $(2 R, 3 R, 4 R)$ ent-3aa and $(2 R, 3 S, 4 R)$-ent-epi-3aa were formed in the reactions catalyzed by thiourea 8 and squaramide sq-8 obtained from $(1 R, 2 R)-1,2$-cyclohexane diamine but surprisingly, ent-epi-3aa was the major diastereoisomer isolated in that case.

The preliminary experiments, collected in Table 1 , show that sq-4 and sq-6, with a dimethylamino substituent, provided better results in terms of yield and stereoselectivity than their piperidyl-substituted homologs sq-5 and sq-7, respectively (compare entries 1 and 3 vs 2 and 4 in Table 1). The catalyst loading can be diminished to $2 \mathrm{~mol} \%$ without affecting the stereoselection, although increasing the reaction time (compare entries 1 and 5 in Table 1). Different solvents were also tested and good chemical yields were obtained for all of them, but very bad stereoselection was observed for ethereal tetrahydrofuran (THF) or alcoholic $(\mathrm{MeOH})$ solvents (compare entry 1 vs 6-9 in Table 1). This fact could be explained because the protic media compete with the catalysts in forming hydrogen bonds with the substrates. Squaramide sq$\mathbf{8}$ is a very active catalyst leading to ent-epi-3aa and ent-3aa in good yield after $8 \mathrm{~h}$ of reaction, but lower stereoselection than sq-4 and sq- 6 (compare entry 11 vs 1 or 3 in Table 1), and its homologous thiourea $\mathbf{8}$ yielded the same mixture of stereo- isomers but without diastereoselection and very low enantioselection (entry 10 in Table 1).

The scope of the reaction was initially studied by stirring, at room temperature, a mixture of ortho-hydroxynitrostyrenes with different substituents $(\mathbf{1} \mathbf{a}-\mathbf{d})$ with two equivalents of a series of $\beta$-aryl-substituted nitroolefins $(2 \mathbf{a}-\mathbf{e})$ or disubstituted nitroalkenes ( $\mathbf{2 f}$ and $\mathbf{2 g}$ ), and $5 \mathrm{~mol} \%$ of organocatalysts sq-4 and sq-6 in dichloromethane (DCM) as solvent (Table 2).

We first explored the influence on the reactivity and stereoselection of the electronic nature of the aryl group in the nitrostyrenes $(\mathbf{2 a}-\mathbf{e})$ acting as acceptors (entries 3-14 in Table 2). As expected, nitroolefins with electron-withdrawing groups $(\mathbf{2 b}-\mathbf{c})$ are more reactive than nitrostyrene or those incorporating an electron-donating group (2d) leading to the final products in shorter reaction time. In general, the reactions occurred with good to excellent stereoselectivity, except for 2naphthyl-derived nitroolefin $2 \mathrm{e}$ which led to the additioncyclization product 3 ae in good enantioselectivity but moderate diastereoselection (entries 12 and 13 in Table 2). It is noteworthy that, contrary to that previously described, ${ }^{24}$ the reactions of nitrostyrenes with electron-withdrawing groups occur with better diastereoselection than those with electron-donating substituents (compare entries 3, 4, 6, 7 vs $10,11)$. Additionally, the data show that sq-4 was the best 
Table 2. Scope of the Reaction

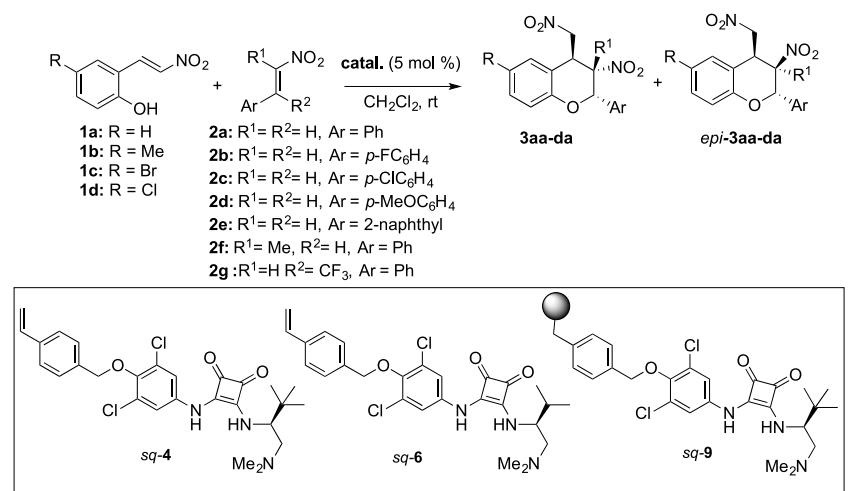

\begin{tabular}{|c|c|c|c|c|c|c|c|c|}
\hline entry $^{a}$ & $1 a-d$ & $2 a-f$ & catalyst & $t(\mathrm{~h})$ & product (yield) ${ }^{b}$ & $\mathrm{dr}^{c} 3 /$ epi-3 & $\mathrm{er}^{c} 3$ & er $^{c}$ epi-3 \\
\hline 1 & $1 \mathrm{a}$ & $2 a$ & sq-9 & 24 & 3aa $(70)$ & $66: 34$ & $78: 22$ & $85: 15$ \\
\hline $2^{d}$ & 1a & $2 a$ & sq-9 & 36 & $3 a a(65)$ & $63: 27$ & $81: 19$ & $81: 19$ \\
\hline 3 & $1 \mathrm{a}$ & $2 b$ & $\mathrm{sq}-4$ & 16 & $3 a b(88)$ & $>99:<1$ & $98: 2$ & \\
\hline 4 & 1a & $2 b$ & sq-6 & 16 & $3 \mathbf{a b}(79)$ & $99: 1$ & $93: 7$ & \\
\hline 5 & 1a & $2 b$ & sq-9 & 16 & $3 a b(86)$ & $>99:<1$ & $87: 13$ & \\
\hline 6 & 1a & $2 c$ & sq-4 & 16 & $3 a c(84)$ & $95: 5$ & $97: 3$ & \\
\hline 7 & 1a & $2 c$ & $\mathrm{sq}-6$ & 16 & $3 a c(68)$ & $67: 33$ & $97: 3$ & $93: 7$ \\
\hline 8 & 1a & $2 \mathrm{c}$ & $\mathrm{sq}-8$ & 24 & $3 a c(75)$ & $22: 78^{e}$ & $90: 10^{e}$ & $92: 8^{e}$ \\
\hline 9 & 1a & $2 c$ & sq-9 & 24 & $3 a c(72)$ & $62: 38$ & $84: 16$ & $96: 4$ \\
\hline 10 & 1a & $2 d$ & $\mathrm{sq}-4$ & 72 & $3 \operatorname{ad}(73)$ & $91: 9$ & $>99:<1$ & $>99:<1$ \\
\hline 11 & 1a & $2 d$ & sq-6 & 72 & $3 \operatorname{ad}(70)$ & $83: 17$ & $>99:<1$ & $88: 12$ \\
\hline 12 & 1a & $2 e$ & sq-4 & 48 & $3 \mathbf{a e}(85)$ & $64: 36$ & $93: 7$ & $92: 8$ \\
\hline 13 & 1a & $2 \mathrm{e}$ & sq-6 & 48 & 3ae (77) & $66: 34$ & $84: 16$ & 99:1 \\
\hline 14 & $1 \mathrm{a}$ & $2 \mathrm{e}$ & sq-9 & 48 & $3 a e(79)$ & $81: 19$ & $78: 22$ & $78: 22$ \\
\hline 15 & $1 b$ & $2 a$ & sq-4 & 72 & $3 \mathbf{b a}(81)$ & $73: 27$ & 90:10 & $82: 18$ \\
\hline 16 & $1 b$ & $2 a$ & sq-9 & 72 & $3 \mathbf{b a}(70)$ & $58: 42$ & $83: 17$ & $80: 20$ \\
\hline 17 & $1 b$ & $2 b$ & $\mathrm{sq}-4$ & 18 & $3 \mathbf{b b}(81)$ & $80: 20$ & $88: 12$ & $>99:<1$ \\
\hline 18 & $1 b$ & $2 c$ & sq-4 & 20 & $3 b c(85)$ & $68: 32$ & $95: 5$ & $97: 3$ \\
\hline 19 & $1 b$ & $2 \mathrm{e}$ & $\mathrm{sq}-4$ & 48 & 3be (64) & $63: 37$ & $88: 12$ & $88: 12$ \\
\hline 20 & $1 c$ & $2 a$ & sq-4 & 16 & $3 \mathrm{ca}(74)$ & 79:21 & $96: 4$ & $>99:<1$ \\
\hline 21 & $1 \mathrm{c}$ & $2 a$ & sq-9 & 24 & $3 \mathrm{ca}(72)$ & $77: 23$ & $82: 18$ & $85: 15$ \\
\hline 22 & $1 \mathrm{c}$ & $2 b$ & sq-4 & 24 & $3 \mathbf{c b}(85)$ & $86: 14$ & $97: 3$ & $>99:<1$ \\
\hline 23 & $1 \mathrm{c}$ & $2 c$ & sq-4 & 24 & $3 \mathrm{cc}(79)$ & $88: 12$ & $93: 7$ & $>99:<1$ \\
\hline 24 & $1 \mathrm{c}$ & $2 e$ & sq-4 & 48 & $3 \mathrm{ce}(76)$ & $78: 22$ & $88: 12$ & $93: 7$ \\
\hline 25 & $1 d$ & $2 a$ & $\mathrm{sq}-4$ & 12 & $3 \mathrm{da}(65)$ & $74: 26$ & $85: 15$ & 89:11 \\
\hline 26 & $1 d$ & $2 a$ & sq-9 & 20 & $3 \mathrm{da}(67)$ & $67: 33$ & $83: 17$ & $87: 13$ \\
\hline 27 & $1 a$ & $2 \mathrm{f}$ & sq-6 & 87 & 3 af $(50)$ & $56: 44$ & $77: 23$ & $56: 44$ \\
\hline
\end{tabular}

${ }^{a}$ The reactions were performed with $1 \mathbf{a}-\mathbf{d}(0.2 \mathrm{mmol})$, nitroolefin $2 \mathrm{a}-\mathbf{e}(0.4 \mathrm{mmol})$, and catalyst $(5 \mathrm{~mol} \%)$ in $\mathrm{CH}_{2} \mathrm{Cl}_{2}(0.6 \mathrm{~mL})$ at rt. ${ }^{b}$ Isolated yield of pure compounds. ${ }^{c}$ Determined by determined by HPLC analysis on a chiral column. ${ }^{d}$ Reaction performed with $2 \%$ of catalyst. ${ }^{e} \mathrm{dr}$ and er correspond to ent-3ac and ent-epi-3ac.

catalyst because it provided higher yields and better stereoselection than sq- 6 (compare entries 3, 6, 10, and 12 vs 4,7 , 11 , and 13 in Table 2).

The reaction was extended to 2-hydroxy nitrostyrenes with different substituents at C-5 $(\mathbf{2} \mathbf{b}-\mathbf{d})$ by using sq-4 as the catalyst (entries 15, 17-20, and 22-25 in Table 2). As a general trend, the presence of a substituent at C-5 in the phenol nucleus decreased the stereoselection, specially the diastereoselectivity, of the reaction (compare entries 15, 20, and 25 in Table 2 with entry 1 in Table 1). This behavior is independent of the electronic characteristic of the substituent (compare entries $17-19$ or $22-24$ vs $3,6,10$, and 12 , respectively, in Table 2).

Attempting to improve the synthetic utility of the cascade reaction, we treated to create quaternary stereocenters by reacting trisubstituted nitroolefins $2 \mathrm{f}$ and $2 \mathrm{~g}$ with $\mathbf{1 a}$. trans $\alpha$ - methyl nitrostyrene $\mathbf{2}$ f reacted very slowly with $\mathbf{1 a}$ by using sq$\mathbf{6}$ as the organocatalyst, leading to 3af in moderate yield, very bad diastereoselection, and moderate enantioselectivity (entry 27 in Table 2). On the contrary, trans- $\beta$-trifluoromethyl nitrostyrene $2 \mathrm{~g}$ was recovered unchanged after $144 \mathrm{~h}$ of stirring with $\mathbf{1 a}$ in the presence of the same organocatalyst. These facts are usually observed in Michael additions and could be probably due to the steric demand on the disubstituted carbon of the double bond. This kind of substitution slows down the intramolecular nitro-Michael addition in intermediate $\mathbf{B}$ (Scheme 1) formed in the reaction of $\mathbf{2} \mathbf{f}$, or the first intermolecular oxa-Michael addition in the reaction of $\mathbf{2} \mathbf{g}$.

Because our main interest was the easy recovering and recycling of the catalyst, we studied the use of squaramide sq$9^{33}$ that is the polymeric homolog of sq-4, as the catalyst (entries 1, 2, 5, 9, 14, 16, 21, and 26 in Table 2). These results 
Scheme 1. Plausible Ternary Complexes That Explain the Formation of Stereoisomers

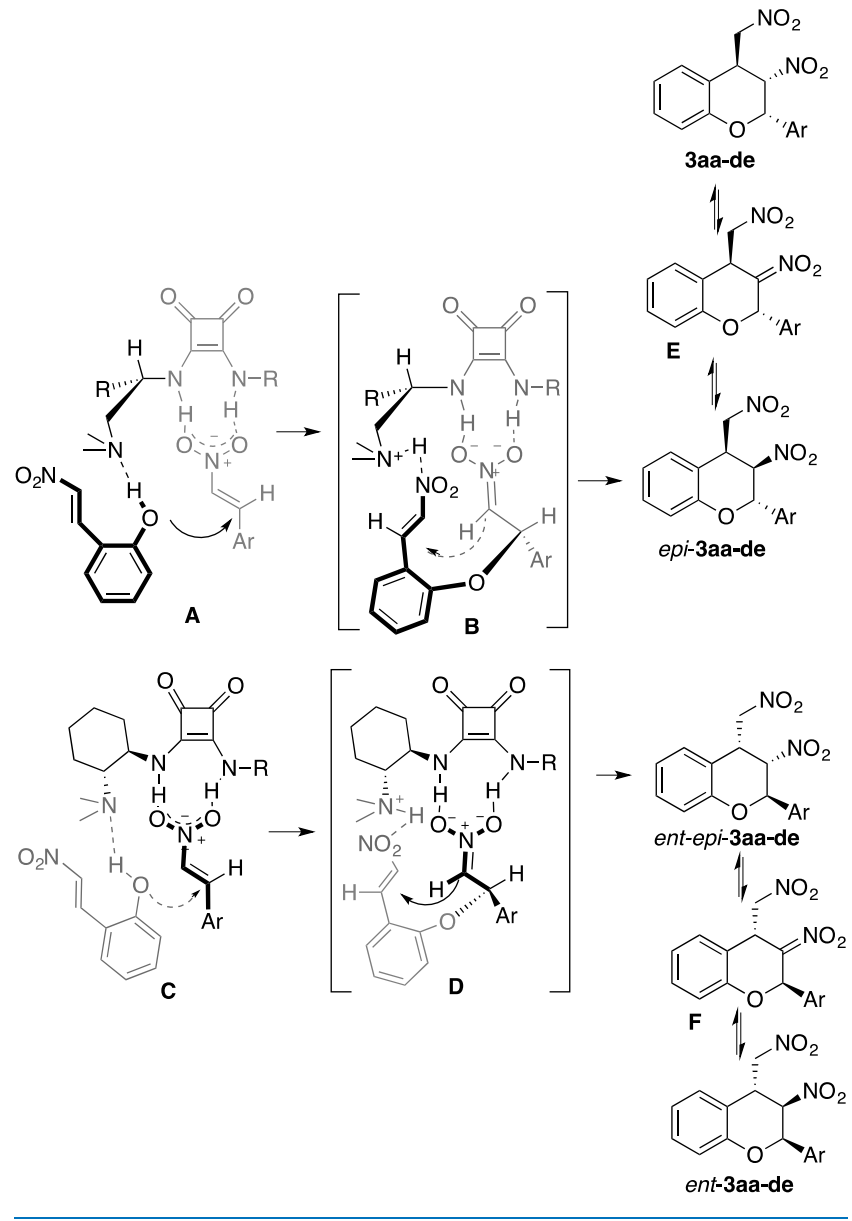

show that the polymeric material was able to promote the stereoselective cascade process, but it was less effective than the monomeric substrate. In general, the processes need longer reaction times, and the reaction was less stereoselective.

The recyclability of polymeric squaramide sq-9 was tested in the reaction of ortho-hydroxynitrostyrene 1a with 4-fluoronitrostyrene $\mathbf{2 b}$ at room temperature in DCM and $5 \mathrm{~mol} \%$ of the catalyst. The mixture of the reaction was stirred until disappearance of 1a thin-layer chromatography (TLC), and the catalyst was isolated by filtration after each cycle, and reused after washing and drying. The results summarized in Table 3 show that sq-9 can be used for five cycles maintaining the activity.

Table 3. Recyclability of Catalyst sq-9 under the Best Reaction Conditions

$\begin{array}{ccccc}\text { cycle }^{a} & t(\mathrm{~h}) & \text { yield }(\%)^{b} & \mathrm{dr}^{c} \text { 3ab/epi-3ab } & \mathrm{er}^{c} \\ 1 & 16 & 86 & >99:<1 & 87: 13 \\ 2 & 16 & 81 & >99:<1 & 84: 16 \\ 3 & 16 & 83 & >99:<1 & 85: 15 \\ 4 & 18 & 78 & >99:<1 & 81: 19 \\ 5 & 18 & 84 & >99:<1 & 86: 14\end{array}$

${ }^{a_{T}}$ The reactions were performed with $\mathbf{1 a}(0.2 \mathrm{mmol})$, nitroolefin $\mathbf{2 b}$ $(0.4 \mathrm{mmol})$, and sq-9 $(5 \mathrm{~mol} \%)$ in $0.6 \mathrm{~mL}$ of DCM at rt. ${ }^{b}$ Yields after purification by flash chromatography. ${ }^{c}$ Determined by HPLC analysis on a chiral stationary phase.
The relative stereochemistry for compound 3 aa and their epimers at C-3 (epi-3aa) were established on the basis of the values of the coupling constants of $\mathrm{H}-2, \mathrm{H}-3$, and $\mathrm{H}-3, \mathrm{H}-4$, as previously described for its 4-phenacyl-substituted homolog. ${ }^{34}$ For 3aa, the values of the coupling constants $\left({ }^{3} J_{\mathrm{H} 2, \mathrm{H} 3}=2.5 \mathrm{~Hz}\right.$, ${ }^{3} \mathrm{~J}_{\mathrm{H} 3 \mathrm{H} 4}=1.8 \mathrm{~Hz}$ ) indicate a cis relationship of the substituents at C-2 and C-3, and trans geometry for the substituents at C-3 and C-4. Additionally, absolute stereochemistry $(2 S, 3 S, 4 S)$ was established by X-ray diffraction analysis for compound 3ac (Figure 1$)^{35}$ and generalized for all compounds 3aa-de. The

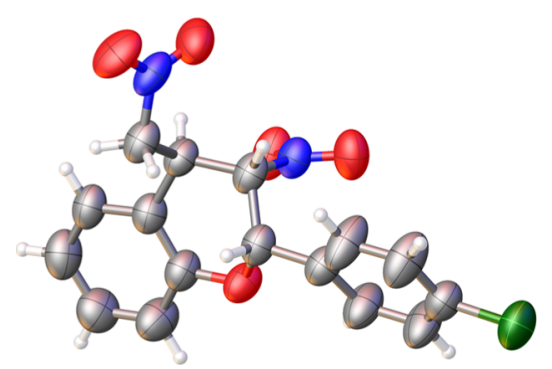

Figure 1. X-ray structure of 3ac (ORTEP representation at 50\% probability ellipsoids).

values of the coupling constants for the same protons $\left({ }^{3} J_{\mathrm{H} 2, \mathrm{H} 3}=\right.$ $6.4 \mathrm{~Hz},{ }^{3} \mathrm{~J}_{\mathrm{H} 3 \mathrm{H} 4}=4.9 \mathrm{~Hz}$ ) also allowed the assignation of the relative stereochemistry as trans for $\mathrm{C}-2-\mathrm{C}-3$ and cis for C-3$\mathrm{C}-4$ substituents in diastereoisomer epi-3aa. In that case, the absolute configuration $(2 S, 3 R, 4 S)$ for these compounds was assigned by accepting that the stereodiscrimination in the first oxa-Michael addition occurs in the same way for the formation of both diastereoisomers.

The formation of enantiomers in the reactions promoted by catalysts derived from $\alpha$-amino acids (sq-4-sq-7) and $(1 R, 2 R)-1,2$-cyclohexanediamine (sq-8) is a consequence of the stereochemistry of the ternary complex formed (Scheme 1 ), but we were intrigued by the fact that catalysts sq-4-7 and sq-8 provided diastereoisomers 3 and ent-epi-3 as major isomers, respectively. In order to clarify that observation, we decided to study the evolution of the reaction of $\mathbf{1 a}$ with $\mathbf{2 a}$ catalyzed by sq- 6 and sq- 8 along the time, and the results are collected in Table 4.

The data collected in Table 4 show that both the major and the ratio of diastereoisomers are dependent on the reaction time. An additional important fact is that epi-3aa (entry 1 in Table 4) or ent-epi-3aa (entry 6) was the first formed diastereoisomer, and the ratio change along the time. For the reaction catalyzed by sq-6, the ratio of 3aa increased over time (entries 1-5 in Table 4) until the reaction finished after $24 \mathrm{~h}$ (entry 4). Both $\mathrm{dr}$ and er were maintained along the time (entries 5, 6 in Table 4). On the contrary, catalyst sq-8 is more active leading to ent-epi-3aa as a major isomer because the reaction time is shorter (entry 8). Interestingly, when the reaction mixture was stirred for longer periods of time, the epimerization of ent-epi-3aa into ent-3aa was observed, obtaining the latter as the major diastereoisomer after $72 \mathrm{~h}$ (entries $8-12$ in Table 4), but only with negligible variations in the enantioselectivity. Interestingly, no changes in the ratio of diastereoisomers, or in the ee were observed when increasing the reaction time (compare entries 11 and 12 in Table 4). It is also interesting to note that $3 a a$ is stable in the solid state, but it epimerizes into a mixture of 3aa/epi-3aa (58/ 42 ) by stirring a solution in DCM for $120 \mathrm{~h}$ without catalysts. 
Table 4. Evolution with Time of the Diastereomeric Composition of the Reaction of $1 \mathrm{a}$ with $2 \mathrm{a}$ and $2 \mathrm{f}$ Catalyzed by $\mathrm{sq}-8$ or $\mathrm{sq}-6^{a}$

$\begin{array}{ccccccc}\text { entry } & \begin{array}{c}\text { time } \\ (\mathrm{h})\end{array} & \begin{array}{c}\text { catalyst } \\ \text { yield } \\ (\%)^{b}\end{array} & \mathrm{dr}^{c} \text { 3aa/epi-3aa } & \begin{array}{c}\text { er 3aa }^{c} \\ \text { er epi-3aa }^{c}\end{array} \\ 1 & 4 & \text { sq-6 } & 36 & 45 / 55 & 82 / 18 & 95 / 5 \\ 2 & 8 & \text { sq-6 } & 52 & 56 / 44 & 83 / 17 & 96 / 4 \\ 3 & 16 & \text { sq-6 } & 77 & 68 / 32 & 83 / 17 & 96 / 4 \\ 4 & 24 & \text { sq-6 } & 100 & 83 / 17 & 84 / 16 & 98 / 2 \\ 5 & 32 & \text { sq-6 } & 100 & 85 / 15 & 83 / 17 & 96 / 4 \\ 6 & 60 & \text { sq-6 } & 100 & 84 / 16 & 83 / 17 & 94 / 4 \\ 7 & 5 & \text { sq-8 } & 83 & 35 / 65 & 74 / 26^{d} & 72 / 28^{d} \\ 8 & 8 & \text { sq-8 } & 100 & 20 / 80 & 74 / 26^{d} & 72 / 28^{d} \\ 9 & 24 & \text { sq-8 } & 100 & 53 / 47 & 76 / 24^{d} & 74 / 26^{d} \\ 10 & 32 & \text { sq-8 } & 100 & 60 / 40 & 74 / 26^{d} & 71 / 29^{d} \\ 11 & 72 & \text { sq-8 } & 100 & 67 / 33 & 74 / 26^{d} & 73 / 27^{d} \\ 12 & 96 & \text { sq-8 } & 100 & 67 / 33 & 74 / 26^{d} & 74 / 26^{d} \\ 13^{e} & 63 & \text { sq-6 } & 58 & 56 / 44 & 77 / 23 & 56 / 44 \\ 14^{e} & 87 & \text { sq-6 } & 66 & 56 / 44 & 77 / 23 & 56 / 44\end{array}$

${ }^{a}$ The reaction was performed with $1 \mathrm{a}(0.25 \mathrm{mmol}), \mathbf{2 a}(0.4 \mathrm{mmol})$, and catalyst $(5 \mathrm{~mol} \%)$ in DCM $(0.6 \mathrm{~mL})$ at rt. ${ }^{b}$ Yields refer to the percent of 1a consumed in the corresponding time. ${ }^{c}$ Measured by HPLC analysis on a chiral column. ${ }^{d}$ er correspond to ent-3aa and entepi-3aa, respectively. ${ }^{e}$ Data refer to the reaction of $\mathbf{2} \mathbf{f}$ with $\mathbf{1 a}$.

All these data show that, in the described reaction conditions, the formation of epi-3aa is kinetically favored, but it can be transformed into thermodynamic 3 aa over the time as previously described for related Michael adducts. ${ }^{34,36}$

The stereochemistry of the products can be explained as summarized in Scheme 1. Bifunctional squaramides are responsible of the activation of the nitroolefin by formation of hydrogen bonds, and help to deprotonate the hydroxyl group leading to ternary complexes $\mathbf{A}$ or $\mathbf{C}$. In those complexes, the first attack occurs to the $\beta$-position of the nitroalkene on the si face in complex $\mathbf{A}$ or on the re face in complex $\mathbf{C}$, leading to nitronates $\mathbf{B}$ and $\mathbf{D}$, respectively. This step is responsible for the formation of the stereocenter at C-2 with configuration $S$ in the first case and $R$ in the second one. Intermediates $\mathbf{B}$ and $\mathbf{D}$ participate in a second intramolecular nitro-Michael addition leading to the cyclization products. The addition of the nitronate by the re face to the $s i$ face of the nitroolefin in $\mathbf{B}$ yields $(2 S, 3 R, 4 S)$-epi-3. On the contrary, the cyclization from $\mathbf{D}$ occurs by the attack of the si face of the nitronate to the re face of the nitroalkene leading to $(2 R, 3 S, 4 R)$-ent-epi-3. The reactions for the enantiotropic faces in complexes $\mathbf{A}$ and $\mathbf{C}$ and their intermediates ( $\mathbf{B}$ or D) explain the formation of both enantiomers depending on the organocatalyst. The extension of the partial conversion of epi-3 into 3 or ent-epi-3 into ent-3 is dependent on the reaction time and may occur through direct epimerization by deprotonation-protonation at the stereogenic center bearing the $\mathrm{NO}_{2}$ group at C-3. This epimerization is supported by the fact that nitroalkene $\mathbf{2 f}$, without hydrogen atom at C-3 does not modify the composition of the mixture of diastereoisomers along the time (entries 13, 14 in Table 4).

\section{CONCLUSIONS}

The described results showed that different squaramides are good catalysts that are able to promote stereoselective cascade reactions leading to enantioenriched 2,3,4-trisubstituted benzopyrans. The enantioselectivity of the process is good, but the observed diastereoselection varies from moderate to excellent. The major diastereoisomer isolated is dependent on the reaction time, and careful control of the catalysts and the reaction conditions will be necessary to obtain the desired diastereoisomers.

\section{EXPERIMENTAL SECTION}

General Information. ${ }^{1} \mathrm{H}$ NMR $(500 \mathrm{MHz})$ and ${ }^{13} \mathrm{C}$ NMR $(126 \mathrm{MHz})$ spectra were recorded in $\mathrm{CDCl}_{3}$ or $\left(\mathrm{CD}_{3}\right)_{2} \mathrm{CO}$ as solvents. Chemical shifts $(\delta)$ are given from TMS, and the residual solvent resonances were taken as the internal reference. A digital polarimeter at $589 \mathrm{~nm}$ (sodium lamp) was used to measure the specific rotation, and concentrations are given in $\mathrm{g}$ per $100 \mathrm{~mL}$. Fourier transform infrared peaks are reported in wave numbers, and only the most structurally important ones are provided. Silica gel (230240 mesh) was used as support for flash chromatography. Melting points are uncorrected and were obtained in open capillary tubes. TLC analysis was carried out on silica gel 60coated glass plates and visualized with a solution of phosphomolybdic acid. Chiral high-performance liquid chromatography (HPLC) analysis was performed on a Lux-iCellulose-5 analytical column $(250 \times 4.6 \mathrm{~mm})$. Elemental analyses were performed at the Elemental Analysis Center of the Complutense University of Madrid.

Commercial compounds were used without additional purification. Solvents were dried by standard procedures. 2(2-Nitrovinyl)phenol derivatives $\mathbf{1 a}-\mathbf{d}^{37}$ and nitroolefins $2 \mathbf{e}^{38}$ and $\mathbf{2} \mathrm{g}^{39}$ were prepared as previously reported. Nitroolefins $\mathbf{1 a}-\mathbf{d}$ and $\mathbf{2 f}$ are commercially available. Chiral bifunctional thiourea 8 and squaramides sq-4-sq-8 ${ }^{33}$ were synthesized as described previously. Racemic samples were obtained in reactions catalyzed by achiral bifunctional thiourea derived from $N^{1}, N^{1}$-dimethylethane-1,2-diamine ${ }^{40}(5 \mathrm{~mol} \%)$ as described for the asymmetric reactions.

Preparation of Polymeric Squaramide sq-9. To a solution of sq-4 $(676 \mathrm{mg}, 1.31 \mathrm{mmol})$ in 1-dodecanol/dry toluene $3: 1(2.5 \mathrm{~mL})$, styrene $(1.5 \mathrm{~mL}, 13.1 \mathrm{mmol})$, divinylbenzene ( $40 \mu \mathrm{L}, 0.26 \mathrm{mmol})$, and azobisisobutyronitrile ( $85 \mathrm{mg}, 0.52 \mathrm{mmol}$ ) were successively added. The mixture was deoxygenated by bubbling nitrogen, and the sealed tube was stirred for $24 \mathrm{~h}$ in an oil bath at $70{ }^{\circ} \mathrm{C}$ and worked-up as previously described ${ }^{33}$ to afford $1.58 \mathrm{~g}$ of sq-9 as a brown solid (89\% yield). IR (ATR): 2922, 2848, 1601, 1491, 807, 756 $\mathrm{cm}^{-1}$. The effective functionalization $\left(f=0.44 \mathrm{mmol} \mathrm{g}^{-1}\right)$ was calculated on the basis of the elemental analysis of nitrogen ( $\mathrm{C}$ : 83.27, H: 7.63, N: 1.87).

General Procedure for the Cascade Reaction of 2-(2Nitrovinyl)phenol Derivatives with Nitroolefins. A mixture of nitroolefin $(0.4 \mathrm{mmol}, 1$ equiv), catalyst $(0.010$ mmol, 0.05 equiv), and 2-(2-nitrovinyl)phenol derivative $(0.2$ mmol, 2 equiv) in $\mathrm{CH}_{2} \mathrm{Cl}_{2}(0.6 \mathrm{~mL})$ was stirred at $\mathrm{rt}$ in a Wheaton vial until the end of the reaction (TLC). The reaction mixture was chromatographed to afford the pure product. In the reaction promoted by a supported material, the catalyst was isolated by filtration and washed with $\mathrm{MeOH}$. The diastereomeric and enantiomeric ratio were determined by HPLC analysis on a chiral column using mixtures of hexane/ isopropanol as the eluant.

(2S, 3S, 4S)-3-Nitro-4-(nitromethyl)-2-phenylchromane (3aa). Obtained as a major diastereomer in the reaction of trans- $\beta$-nitrostyrene ( $60 \mathrm{mg}, 0.4 \mathrm{mmol}, 2$ equiv), catalyst sq- 6 ( $5 \mathrm{mg}, 0.01 \mathrm{mmol}, 0.05$ equiv), and 2-(2-nitrovinyl)phenol 1a 
(33 mg, $0.2 \mathrm{mmol}, 1$ equiv) to yield compound $3 \mathrm{aa}(51 \mathrm{mg}$, $0.16 \mathrm{mmol}, 80 \%$ combined yield). Yellow solid. mp 133-135 ${ }^{\circ} \mathrm{C}\left[\right.$ lit. $\left.^{24} \mathrm{mp} 165-168{ }^{\circ} \mathrm{C}\right] .[\alpha]_{\mathrm{D}}^{23}+101.2\left(c \quad 0.9, \mathrm{CH}_{2} \mathrm{Cl}_{2}\right)$ $\left[\right.$ lit. $^{24}[\alpha]_{\mathrm{D}}^{22}+103.1\left(c 0.3, \mathrm{CH}_{2} \mathrm{Cl}_{2}, 94 \%\right.$ ee, $\left.\left.>20: 1 \mathrm{dr}\right)\right] .{ }^{1} \mathrm{H}$ NMR $\left(500 \mathrm{MHz}, \mathrm{CDCl}_{3}\right): \delta 4.25(\mathrm{~m}, 1 \mathrm{H}), 4.79\left(\mathrm{dd}, J_{1}=13.6\right.$ $\left.\mathrm{Hz}, J_{2}=10.4 \mathrm{~Hz}, 1 \mathrm{H}\right), 4.91\left(\mathrm{dd}, J_{1}=13.6 \mathrm{~Hz}, J_{2}=4.1 \mathrm{~Hz}\right)$, $5.23\left(\mathrm{dd}, J_{1}=2.5 \mathrm{~Hz}, J_{2}=1.8 \mathrm{~Hz}, 1 \mathrm{H}\right), 5.36(\mathrm{~d}, J=2.5 \mathrm{~Hz}$, $1 \mathrm{H}), 7.10(\mathrm{~m}, 2 \mathrm{H}), 7.28(\mathrm{~d}, J=0.7 \mathrm{~Hz}, 1 \mathrm{H}), 7.32\left(\mathrm{dd}, J_{1}=7.4\right.$ $\left.\mathrm{Hz}, J_{2}=0.7 \mathrm{~Hz}, 1 \mathrm{H}\right), 7.41-7.46(\mathrm{~m}, 5 \mathrm{H})$. HPLC: (Lux iCellulose-5, $n$-hexane/isopropanol $=90: 10,1.0 \mathrm{~mL} / \mathrm{min}, \lambda=$ $210 \mathrm{~nm}$ ) $t_{\mathrm{R}}=17.1 \min$ (major, $2 S, 3 S, 4 S$ ), $t_{\mathrm{R}}=19.7$ (minor, $2 R, 3 R, 4 R)$. (dr 83:17; er 84:16).

(2S,3R,4S)-3-Nitro-4-(nitromethyl)-2-phenylchromane (epi-3aa). Obtained as a minor diastereomer in the reaction of trans- $\beta$-nitrostyrene, catalyst sq-6, and 2-(2-nitrovinyl)phenol 1a. ${ }^{1} \mathrm{H}$ NMR (500 MHz, $\mathrm{CDCl}_{3}$ ): $\delta 4.25(\mathrm{~m}, 1 \mathrm{H}), 4.94\left(\mathrm{dd}, J_{1}\right.$ $\left.=14.5 \mathrm{~Hz}, J_{2}=6.1 \mathrm{~Hz}, 1 \mathrm{H}\right), 5.00\left(\mathrm{dd}, J_{1}=14.5 \mathrm{~Hz}, J_{2}=7.4\right.$ $\mathrm{Hz}, 1 \mathrm{H}), 5.28\left(\mathrm{dd}, J_{1}=6.6 \mathrm{~Hz}, J_{2}=4.6 \mathrm{~Hz}, 1 \mathrm{H}\right), 5.75(\mathrm{~d}, J=$ $6.6 \mathrm{~Hz}, 1 \mathrm{H}), 7.05(\mathrm{~m}, 2 \mathrm{H}), 7.09(\mathrm{~m}, 1 \mathrm{H}), 7.31(\mathrm{~m}, 1 \mathrm{H}), 7.36-$ $7.43(\mathrm{~m}, 5 \mathrm{H}) .{ }^{13} \mathrm{C}$ NMR $\left(126 \mathrm{MHz}, \mathrm{CDCl}_{3}\right): \delta 34.5,75.6$, 75.7, 84.4, 117.5, 122.4, 126.3, 127.2, 129.1, 129.2, 129.4, 132.1, 135.6, 152.5. IR (ATR): 2930, 1716, 1552, 1487, 757, 700, $581 \mathrm{~cm}^{-1}$. HRMS (ESI-QTOF) $\mathrm{m} / z$ : calcd for $\mathrm{C}_{16} \mathrm{H}_{14} \mathrm{~N}_{2} \mathrm{O}_{5}+\mathrm{Na}$, 337.0797; found, 337.0796. HPLC: (Lux i-Cellulose-5, $n$-hexane/isopropanol $=90: 10,1.0 \mathrm{~mL} / \mathrm{min}, \lambda=$ $210 \mathrm{~nm}) t_{\mathrm{R}}=24.2$ (major, $2 S, 3 R, 4 S$ ), $t_{\mathrm{R}}=55.2$ (minor, $2 R, 3 S, 4 R)$. (er $>99:<1)$.

(2S,3S,4S)-2-(4-Fluorophenyl)-3-nitro-4-(nitromethyl)chromane (3ab). Obtained as a major diastereomer in the reaction of (E)-1-fluoro-4-(2-nitrovinyl)benzene (67 mg, 0.4 mmol, 2 equiv), catalyst sq-4 ( $5 \mathrm{mg}, 0.01 \mathrm{mmol}, 0.05$ equiv), and 2-(2-nitrovinyl)phenol $1 \mathrm{a}$ ( $33 \mathrm{mg}, 0.2 \mathrm{mmol}, 1$ equiv) to yield compound $3 \mathrm{ab}$ ( $58 \mathrm{mg}, 0.17 \mathrm{mmol}, 88 \%$ ). Yellow solid. mp 88-91 ${ }^{\circ} \mathrm{C}\left[\right.$ lit. $\left.^{24} \mathrm{mp} 135-137{ }^{\circ} \mathrm{C}\right]$. $[\alpha]_{\mathrm{D}}^{23}+110.0$ (c 1.0, $\left.\mathrm{CH}_{2} \mathrm{Cl}_{2}\right)\left[\right.$ lit. $^{24}[\alpha]_{\mathrm{D}}^{22}+114.513\left(c 0.6, \mathrm{CH}_{2} \mathrm{Cl}_{2}, 93 \%\right.$ ee, $13: 1$ dr) ]. ${ }^{1} \mathrm{H}$ NMR (500 MHz, $\left.\left(\mathrm{CD}_{3}\right)_{2} \mathrm{CO}\right): \delta 4.46(\mathrm{~m}, 1 \mathrm{H}), 5.17$ $\left(\mathrm{dd}, J_{1}=15.7 \mathrm{~Hz}, J_{2}=3.8 \mathrm{~Hz}, 1 \mathrm{H}\right), 5.30\left(\mathrm{dd}, J_{1}=15.7 \mathrm{~Hz}, J_{2}=\right.$ $10.2 \mathrm{~Hz}, 1 \mathrm{H}), 5.66\left(\mathrm{dd}, J_{1}=3.3 \mathrm{~Hz}, J_{2}=2.3 \mathrm{~Hz}, 1 \mathrm{H}\right), 5.77(\mathrm{~d}$, $J=2.3 \mathrm{~Hz}, 1 \mathrm{H}), 7.06-7.12(\mathrm{~m}, 2 \mathrm{H}), 7.20-7.24(\mathrm{~m}, 2 \mathrm{H}), 7.31$ $(\mathrm{m}, 1 \mathrm{H}), 7.57-7.59(\mathrm{~m}, 1 \mathrm{H}), 7.62-7.65(\mathrm{~m}, 2 \mathrm{H})$. HPLC: (Lux i-Cellulose-5, $n$-hexane/isopropanol $=90: 10,1.0 \mathrm{~mL} /$ min, $\lambda=210 \mathrm{~nm}$ ) $t_{\mathrm{R}}=31.9 \min$ (major, $\left.2 S, 3 S, 4 S\right), t_{\mathrm{R}}=35.9$ $\min ($ minor, $2 R, 3 R, 4 R)$. $(\mathrm{dr}>99:<1$; er $98: 2)$.

(2S,3R,4S)-2-(4-Fluorophenyl)-3-nitro-4-(nitromethyl)chromane (epi-3ab). Obtained as a minor diastereomer in the reaction of (E)-1-fluoro-4-(2-nitrovinyl)benzene, catalyst sq-4, and 2-(2-nitrovinyl)phenol 1a. ${ }^{1} \mathrm{H}$ NMR (500 $\left.\mathrm{MHz}, \mathrm{CDCl}_{3}\right)$ : $\delta 4.31(\mathrm{~m}, 1 \mathrm{H}), 4.90\left(\mathrm{dd}, J_{1}=14.6 \mathrm{~Hz}, J_{2}=6.0 \mathrm{~Hz}, 1 \mathrm{H}\right), 5.01$ $\left(\mathrm{dd}, J_{1}=14.6 \mathrm{~Hz}, J_{2}=7.5 \mathrm{~Hz}, 1 \mathrm{H}\right), 5.24\left(\mathrm{dd}, J_{1}=7.3 \mathrm{~Hz}, J_{2}=\right.$ $4.7 \mathrm{~Hz}, 1 \mathrm{H}), 5.67(\mathrm{~d}, J=7.3 \mathrm{~Hz}, 1 \mathrm{H}), 7.03(\mathrm{~m}, 3 \mathrm{H}), 7.11(\mathrm{~m}$, $3 \mathrm{H}), 7.37(\mathrm{~m}, 2 \mathrm{H}) .{ }^{13} \mathrm{C}$ NMR $\left(126 \mathrm{MHz}, \mathrm{CDCl}_{3}\right): \delta 34.9$, $74.8,75.7,84.5,116.2,116.4,117.6,122.6,127.5,128.4,128.5$, 130.3, 131.3, 152.4. IR (ATR): $1545,1487,823,755 \mathrm{~cm}^{-1}$. HPLC: (Lux i-Cellulose-5, $n$-hexane/isopropanol $=90: 10,0.5$ $\mathrm{mL} / \mathrm{min}, \lambda=210 \mathrm{~nm}$ ) $t_{\mathrm{R}}=20.4 \min$ (major, $2 S, 3 R, 4 S$ ), $t_{\mathrm{R}}=$ $22.2 \mathrm{~min}$ (minor, $2 R, 3 S, 4 R$ ).

(2S,3S,4S)-2-(4-Chlorophenyl)-3-nitro-4-(nitromethyl)chromane (3ac). Obtained as a major diastereomer in the reaction of $(E)$-1-chloro-4-(2-nitrovinyl)benzene $(73 \mathrm{mg}, 0.4$ mmol, 2 equiv), catalyst sq-4 ( $5 \mathrm{mg}, 0.01 \mathrm{mmol}, 0.05$ equiv), and 2-(2-nitrovinyl)phenol $1 \mathrm{a}(33 \mathrm{mg}, 0.2 \mathrm{mmol}, 1$ equiv) to yield compound 3 ac $(58 \mathrm{mg}, 0.16 \mathrm{mmol}, 84 \%)$. Yellow solid. $\mathrm{mp} 122-124{ }^{\circ} \mathrm{C}\left[\mathrm{lit}^{24} \mathrm{mp} 139-141{ }^{\circ} \mathrm{C}\right] .[\alpha]_{\mathrm{D}}^{23}+71.6$ (c 1.0,
$\left.\mathrm{CH}_{2} \mathrm{Cl}_{2}\right)\left[\right.$ lit. $^{24}[\alpha]_{\mathrm{D}}^{22}+98.2\left(\right.$ c $1.0, \mathrm{CH}_{2} \mathrm{Cl}_{2}, 92 \%$ ee, $\left.\left.>20: 1 \mathrm{dr}\right)\right]$. ${ }^{1} \mathrm{H}$ NMR (500 MHz, $\left.\left(\mathrm{CD}_{3}\right)_{2} \mathrm{CO}\right): \delta 4.26(\mathrm{~m}, 1 \mathrm{H}), 4.78\left(\mathrm{dd}, J_{1}\right.$ $\left.=13.5 \mathrm{~Hz}, J_{2}=10.4 \mathrm{~Hz}, 1 \mathrm{H}\right), 4.91(\mathrm{~m}, 1 \mathrm{H}), 5.20(\mathrm{~m}, 1 \mathrm{H})$, $5.32(\mathrm{~d}, J=2.3 \mathrm{~Hz}, 1 \mathrm{H}), 7.08(\mathrm{~m}, 1 \mathrm{H}), 7.11(\mathrm{~m}, 1 \mathrm{H}), 7.28(\mathrm{~m}$, $1 \mathrm{H}), 7.31-7.37(\mathrm{~m}, 3 \mathrm{H}), 7.42(\mathrm{~m}, 2 \mathrm{H})$. HPLC: (Lux iCellulose-5, $n$-hexane/isopropanol $=95: 5,1.0 \mathrm{~mL} / \mathrm{min}, \lambda=$ $210 \mathrm{~nm}) t_{\mathrm{R}}=27.3 \mathrm{~min}$ (major, $2 S, 3 S, 4 S$ ), $t_{\mathrm{R}}=31.7 \mathrm{~min}$ (minor, 2R,3R,4R). (dr 95:5; er 97:3).

(2S,3R,4S)-2-(4-Chlorophenyl)-3-nitro-4-(nitromethyl)chromane (epi-3ac). Obtained as a minor diastereomer in the reaction of (E)-1-chloro-4-(2-nitrovinyl)benzene, catalyst sq-4, and 2-(2-nitrovinyl)phenol 1a. ${ }^{1} \mathrm{H}$ NMR (500 $\left.\mathrm{MHz}, \mathrm{CDCl}_{3}\right)$ : $\delta 4.27(\mathrm{~m}, 1 \mathrm{H}), 4.92\left(\mathrm{dd}, J_{1}=14.6 \mathrm{~Hz}, J_{2}=6.0 \mathrm{~Hz}, 1 \mathrm{H}\right), 5.00$ $\left(\mathrm{dd}, J_{1}=14.5 \mathrm{~Hz}, J_{2}=7.5 \mathrm{~Hz} 1 \mathrm{H}\right), 5.23\left(\mathrm{dd}, J_{1}=7.0 \mathrm{~Hz}, J_{2}=\right.$ $4.7 \mathrm{~Hz}, 1 \mathrm{H}), 5.69$ (d, $J=7.0 \mathrm{~Hz}, 1 \mathrm{H}), 7.03(\mathrm{~m}, 2 \mathrm{H}), 7.32(\mathrm{~m}$, $3 \mathrm{H}), 7.39(\mathrm{~m}, 3 \mathrm{H}) .{ }^{13} \mathrm{C} \mathrm{NMR}\left(126 \mathrm{MHz} \mathrm{CDCl}_{3}\right): \delta 34.7$, 74.9, 75.6, 84.3, 116.9, 117.6, 122.7, 127.4, 127.8, 129.5, 130.3, 134.0, 135.7, 152.3. IR (ATR): 1546, 1489, 820, $755 \mathrm{~cm}^{-1}$. HRMS (ESI-QTOF) $m / z$ : calcd for $\mathrm{C}_{16} \mathrm{H}_{13} \mathrm{ClN}_{2} \mathrm{O}_{5}+\mathrm{Na}$, 371.0408; found, 371.0406. HPLC: (Lux i-Cellulose-5, $n$ hexane/isopropanol $=95: 5,1.0 \mathrm{~mL} / \mathrm{min}, \lambda=210 \mathrm{~nm}) t_{\mathrm{R}}=$ 13.8 min (major, $2 S, 3 R, 4 S$ ), $t_{\mathrm{R}}=38.9 \min$ (minor, $2 R, 3 S, 4 R$ ). (er $74: 26)$.

(2S,3S,4S)-2-(4-Methoxyphenyl)-3-nitro-4-(nitromethyl)chromane (3ad). Obtained as a major diastereomer in the reaction of (E)-1-methoxy-4-(2-nitrovinyl)benzene (72 $\mathrm{mg}$, $0.4 \mathrm{mmol}, 2$ equiv), catalyst sq-4 $(5 \mathrm{mg}, 0.01 \mathrm{mmol}, 0.05$ equiv), and 2-(2-nitrovinyl)phenol $1 \mathrm{a}(33 \mathrm{mg}, 0.2 \mathrm{mmol}, 1$ equiv) to yield compound $3 \mathrm{ad}(50 \mathrm{mg}, 0.15 \mathrm{mmol}, 73 \%$ ). Yellow solid. mp $176-178{ }^{\circ} \mathrm{C}\left[\right.$ lit. $\left.^{24} \mathrm{mp} 198-199{ }^{\circ} \mathrm{C}\right] .[\alpha]_{\mathrm{D}}^{23}$ +109.1 ( c 1.0, $\left.\mathrm{CH}_{2} \mathrm{Cl}_{2}\right)\left[\right.$ lit. $^{24}[\alpha]_{\mathrm{D}}^{22}+147.5$ (c $0.2, \mathrm{CH}_{2} \mathrm{Cl}_{2}$, $>99 \%$ ee, $>20: 1 \mathrm{dr})] .{ }^{1} \mathrm{H}$ NMR $\left(500 \mathrm{MHz},\left(\mathrm{CD}_{3}\right)_{2} \mathrm{CO}\right): \delta 3.82$ (s, 3H), $4.40(\mathrm{~m}, 1 \mathrm{H}), 5.17(\mathrm{~m}, 1 \mathrm{H}), 5.28(\mathrm{~m}, 1 \mathrm{H}), 5.58(\mathrm{~d}, J$ $=2.5 \mathrm{~Hz}, 1 \mathrm{H}), 5.67(\mathrm{~m}, 1 \mathrm{H}), 6.99(\mathrm{~m}, 2 \mathrm{H}), 7.06(\mathrm{~m}, 2 \mathrm{H})$, $7.31(\mathrm{~m}, 1 \mathrm{H}), 7.47(\mathrm{~m}, 2 \mathrm{H}), 7.55(\mathrm{~m}, 1 \mathrm{H})$. HPLC: (Lux iCellulose- $5, n$-hexane/isopropanol $=90: 10,1.0 \mathrm{~mL} / \mathrm{min}, \lambda=$ $210 \mathrm{~nm}) t_{\mathrm{R}}=34.9 \min$ (major, $2 S, 3 S, 4 S$ ), $t_{\mathrm{R}}=37.2 \mathrm{~min}$ (minor, 2R,3R,4R). (dr 91:9; er $>99:<1)$.

(2S,3S,4S)-2-(Naphthalen-2-yl)-3-nitro-4-(nitromethyl)chromane (3ae). Obtained as a major diastereomer in the reaction of $(E)-2$-(2-nitrovinyl)naphthalene ${ }^{38}(80 \mathrm{mg}, 0.4$ mmol, 2 equiv), catalyst sq-4 ( $5 \mathrm{mg}, 0.01 \mathrm{mmol}, 0.05$ equiv), and 2-(2-nitrovinyl)phenol $1 \mathrm{a}(33 \mathrm{mg}, 0.2 \mathrm{mmol}, 1$ equiv) to yield compound 3ae $(61 \mathrm{mg}, 0.17 \mathrm{mmol}, 85 \%)$. Yellow solid. mp 107-110 ${ }^{\circ} \mathrm{C}\left[\right.$ lit. $\left.^{24} \mathrm{mp} 172-175{ }^{\circ} \mathrm{C}\right]$. $[\alpha]_{\mathrm{D}}^{23}+115.1$ (c 1.0, $\mathrm{CH}_{2} \mathrm{Cl}_{2}$ ) $\left[\right.$ lit. $^{24}[\alpha]_{\mathrm{D}}^{22}+125.0\left(c 0.1, \mathrm{CH}_{2} \mathrm{Cl}_{2},>99 \%\right.$ ee, $>20: 1$ dr) ]. ${ }^{1} \mathrm{H}$ NMR (500 MHz, $\left.\left(\mathrm{CD}_{3}\right)_{2} \mathrm{CO}\right): \delta 4.51\left(\mathrm{dd}, J_{1}=10.2\right.$ $\left.\mathrm{Hz}, J_{2}=3.8 \mathrm{~Hz}, 1 \mathrm{H}\right), 5.22\left(\mathrm{dd}, J_{1}=15.6 \mathrm{~Hz}, J_{2}=3.8 \mathrm{~Hz}, 1 \mathrm{H}\right)$, $5.39\left(\mathrm{dd}, J_{1}=15.6 \mathrm{~Hz}, J_{2}=10.1 \mathrm{~Hz}, 1 \mathrm{H}\right), 5.79\left(\mathrm{dd}, J_{1}=2.4\right.$ $\left.\mathrm{Hz}, J_{2}=1.0 \mathrm{~Hz}, 1 \mathrm{H}\right), 5.94(\mathrm{~d}, J=2.3 \mathrm{~Hz}, 1 \mathrm{H}), 7.13(\mathrm{~m}, 2 \mathrm{H})$, $7.35(\mathrm{~m}, 1 \mathrm{H}), 7.56(\mathrm{~m}, 2 \mathrm{H}), 7.60-7.62(\mathrm{~m}, \mathrm{H}), 7.71(\mathrm{~m}, \mathrm{H})$, 7.94-7.99 (m, 3H), 8.13 (m, 1H). HPLC: (Lux i-Cellulose-5, $n$-hexane $/$ isopropanol $=90: 10,1.0 \mathrm{~mL} / \mathrm{min}, \lambda=210 \mathrm{~nm}) t_{\mathrm{R}}=$ 24.7 min (major, $2 S, 3 S, 4 S$ ), $t_{\mathrm{R}}=31.4 \mathrm{~min}$ (minor, $2 R, 3 R, 4 R$ ). (dr 64:36; er 93:7).

(2S,3R,4S)-2-(Naphthalen-2-yl)-3-nitro-4-(nitromethyl)chromane (epi-3ae). Obtained as a minor diastereomer in the reaction of (E)-2-(2-nitrovinyl)naphthalene, catalyst sq-4, and 2-(2-nitrovinyl)phenol 1a. ${ }^{1} \mathrm{H} \mathrm{NMR}\left(500 \mathrm{MHz},\left(\mathrm{CD}_{3}\right)_{2} \mathrm{CO}\right)$ : $\delta 4.47\left(\mathrm{dt}, J_{1}=7.5 \mathrm{~Hz}, J_{2}=4.9 \mathrm{~Hz}, 1 \mathrm{H}\right), 5.25\left(\mathrm{dd}, J_{1}=15.7\right.$ $\left.\mathrm{Hz}, J_{2}=5.2 \mathrm{~Hz}, 1 \mathrm{H}\right), 5.40\left(\mathrm{dd}, J_{1}=15.7 \mathrm{~Hz}, J_{2}=7.5 \mathrm{~Hz}, 1 \mathrm{H}\right)$, $5.91\left(\mathrm{dd}, J_{1}=6.7 \mathrm{~Hz}, J_{2}=4.6 \mathrm{~Hz}, 1 \mathrm{H}\right), 6.17(\mathrm{~d}, J=6.7 \mathrm{~Hz}$, $1 \mathrm{H}), 7.07(\mathrm{~m}, 2 \mathrm{H}), 7.33-7.37(\mathrm{~m}, 2 \mathrm{H}), 7.54-7.58(\mathrm{~m}, 2 \mathrm{H})$, 
$7.70(\mathrm{~m}, 1 \mathrm{H}), 7.71-7.96(\mathrm{~m}, 2 \mathrm{H}), 8.00(\mathrm{~m}, 1 \mathrm{H}), 8.07(\mathrm{~m}$, $1 \mathrm{H}) .{ }^{13} \mathrm{C}$ NMR $\left(126 \mathrm{MHz},\left(\mathrm{CD}_{3}\right)_{2} \mathrm{CO}\right): \delta 34.4,75.5,75.6$, $84.3,116.9,118.3,122.0,123.8,126.6,126.7,126.8,127.7$, $128.1,128.8,129.5,133.1,133.6,133.9,153.0$. IR (ATR): 1554, 1485, 829, $747 \mathrm{~cm}^{-1}$. HRMS (ESI-QTOF) $\mathrm{m} / z$ : calcd for $\mathrm{C}_{20} \mathrm{H}_{16} \mathrm{~N}_{2} \mathrm{O}_{5}+\mathrm{Na}$, 387.0958; found, 387.0953. HPLC: (Lux i-Cellulose-5, $n$-hexane/isopropanol $=90: 10,1.0 \mathrm{~mL} /$ min, $\lambda=210 \mathrm{~nm}$ ) $t_{\mathrm{R}}=34.0$ min (major, $\left.2 S, 3 R, 4 S\right), t_{\mathrm{R}}=82.6$ min (minor, $2 R, 3 S, 4 R$ ). (er 92:8).

(2S,3S,4S)-6-Methyl-3-nitro-4-(nitromethyl)-2-phenylchromane (3ba). Obtained as a major diastereomer in the reaction of trans- $\beta$-nitrostyrene ( $60 \mathrm{mg}, 0.4 \mathrm{mmol}, 2$ equiv), catalyst sq-4 ( $5 \mathrm{mg}, 0.01 \mathrm{mmol}, 0.05$ equiv), and (E)-4-methyl2-(2-nitrovinyl)phenol $\mathbf{1 b}(36 \mathrm{mg}, 0.2 \mathrm{mmol}, 1$ equiv) to yield compound $3 \mathrm{ba}(53 \mathrm{mg}, 0.16 \mathrm{mmol}, 81 \%)$. Yellow solid. $\mathrm{mp}$ 125-127 ${ }^{\circ} \mathrm{C}$. $[\alpha]_{\mathrm{D}}^{23}+119.3\left(\right.$ c $\left.1.0, \mathrm{CH}_{2} \mathrm{Cl}_{2}\right) \cdot{ }^{1} \mathrm{H}$ NMR $(500$ $\left.\mathrm{MHz} \mathrm{CDCl}_{3}\right): \delta 2.34(\mathrm{~s}, 3 \mathrm{H}), 4.21\left(\mathrm{ddd}, J_{1}=10.5 \mathrm{~Hz}, J_{2}=4.1\right.$ $\left.\mathrm{Hz}, J_{3}=1.6 \mathrm{~Hz}\right), 4.76\left(\mathrm{dd}, J_{1}=13.6 \mathrm{~Hz}, J_{2}=10.5 \mathrm{~Hz}, 1 \mathrm{H}\right)$, $4.90\left(\mathrm{dd}, J_{1}=13.6 \mathrm{~Hz}, J_{2}=4.0 \mathrm{~Hz}, 1 \mathrm{H}\right), 5.19(\mathrm{~m}, 1 \mathrm{H}), 5.31(\mathrm{~d}$, $J=2.4 \mathrm{~Hz}, 1 \mathrm{H}), 6.98(\mathrm{~d}, J=8.3 \mathrm{~Hz}, 1 \mathrm{H}), 7.06(\mathrm{~m}, 1 \mathrm{H}), 7.12$ $(\mathrm{m}, 1 \mathrm{H}), 7.40-7.45(\mathrm{~m}, 5 \mathrm{H}) .{ }^{13} \mathrm{C} \mathrm{NMR}\left(126 \mathrm{MHz} \mathrm{CDCl}_{3}\right): \delta$ 20.7, 37.0, 73.3, 78.5, 84.1, 115.4, 117.8, 125.6, 128.6, 128.9, 129.2, 130.6, 132.3, 134.6, 151.9. IR (ATR): 1552, 1503, 818, 757, $704 \mathrm{~cm}^{-1}$. HRMS (ESI-QTOF) $\mathrm{m} / z$ : calcd for $\mathrm{C}_{17} \mathrm{H}_{16} \mathrm{~N}_{2} \mathrm{O}_{5}+\mathrm{Na}$, 351.0997; found, 351.0958. HPLC: (Lux i-Cellulose-5, $n$-hexane/isopropanol $=90: 10,1.0 \mathrm{~mL} / \mathrm{min}, \lambda=$ $210 \mathrm{~nm}) t_{\mathrm{R}}=14.1 \mathrm{~min}$ (major, $2 S, 3 S, 4 S$ ), $t_{\mathrm{R}}=18.1 \mathrm{~min}$ (minor, 2R,3R,4R). (dr 73:27; er 90:10).

(2S,3R,4S)-6-Methyl-3-nitro-4-(nitromethyl)-2-phenylchromane (epi-3ba). Obtained as a minor diastereomer in the reaction of trans- $\beta$-nitrostyrene, catalyst sq-4, and (E)-4methyl-2-(2-nitrovinyl)phenol 1b. ${ }^{1} \mathrm{H}$ NMR (500 $\mathrm{MHz}$, $\left.\mathrm{CDCl}_{3}\right): \delta 2.30(\mathrm{~s}, 3 \mathrm{H}), 4.20(\mathrm{~m}, 1 \mathrm{H}), 4.93\left(\mathrm{dd}, J_{1}=14.6\right.$ $\left.\mathrm{Hz}, J_{2}=6.0 \mathrm{~Hz}, 1 \mathrm{H}\right), 5.00\left(\mathrm{dd}, J_{1}=14.5 \mathrm{~Hz}, J_{2}=7.5 \mathrm{~Hz}, 1 \mathrm{H}\right)$, $5.26\left(\mathrm{dd}, J_{1}=6.7 \mathrm{~Hz}, J_{2}=4.6 \mathrm{~Hz}, 1 \mathrm{H}\right), 5.71(\mathrm{~d}, J=6.6 \mathrm{~Hz}$, $1 \mathrm{H}), 6.87(\mathrm{~s}, 1 \mathrm{H}), 6.92(\mathrm{~d}, 1 \mathrm{H}, J=8.3 \mathrm{~Hz}), 7.10(\mathrm{~m}, 1 \mathrm{H})$, 7.35-7.42 (m, 5H). ${ }^{13} \mathrm{C} \mathrm{NMR}\left(126 \mathrm{MHz}, \mathrm{CDCl}_{3}\right): \delta 20.6$, $34.5,75.6,75.7,84.6,116.7,117.3,126.2,127.3,129.2,129.5$, $130.8,131.9,135.7,150.3$. HRMS (ESI-QTOF) $\mathrm{m} / z$ : calcd for $\mathrm{C}_{17} \mathrm{H}_{16} \mathrm{~N}_{2} \mathrm{O}_{5}+\mathrm{Na}$, 351.0997; found, 351.0959. IR (ATR): 1554, 1497, 816, 751, $694 \mathrm{~cm}^{-1}$. HPLC: (Lux i-Cellulose-5, $n$ hexane/isopropanol $=90: 10,1.0 \mathrm{~mL} / \mathrm{min}, \lambda=210 \mathrm{~nm}) t_{\mathrm{R}}=$ $23.9 \min$ (major, $2 S, 3 R, 4 S$ ), $t_{\mathrm{R}}=54.7 \mathrm{~min}$ (minor, $2 R, 3 S, 4 R$ ). (er 82:18).

(2S,3S, 4S)-2-(4-Fluorophenyl)-6-methyl-3-nitro-4(nitromethyl)chromane ( $3 b b)$. Obtained as a major diastereomer in the reaction of trans-4-fluoro- $\beta$-nitrostyrene $(67 \mathrm{mg}$, $0.4 \mathrm{mmol}, 2$ equiv), catalyst sq-4 (5 mg, $0.01 \mathrm{mmol}, 0.05$ equiv), and (E)-4-methyl-2-(2-nitrovinyl)phenol $\mathbf{1 b}(36 \mathrm{mg}$, $0.2 \mathrm{mmol}, 1$ equiv) to yield compound $3 \mathbf{b b}(55 \mathrm{mg}, 0.16$ mmol, 81\%). Yellow solid. mp $99-101^{\circ} \mathrm{C}$. $[\alpha]_{\mathrm{D}}^{23}+137.5(c 1.0$, $\mathrm{CH}_{2} \mathrm{Cl}_{2}$ ). ${ }^{1} \mathrm{H}$ NMR (500 MHz, $\mathrm{CDCl}_{3}$ ): $\delta 2.32(\mathrm{~s}, 3 \mathrm{H}), 4.20$ $(\mathrm{m}, 1 \mathrm{H}), 4.72\left(\mathrm{dd}, J_{1}=14.5 \mathrm{~Hz}, J_{2}=5.9 \mathrm{~Hz}, 1 \mathrm{H}\right), 4.86\left(\mathrm{dd}, J_{1}\right.$ $\left.=14.5 \mathrm{~Hz}, J_{2}=7.5 \mathrm{~Hz}, 1 \mathrm{H}\right), 5.14(\mathrm{~m}, 1 \mathrm{H}), 5.26(\mathrm{~d}, J=6.7 \mathrm{~Hz}$, $1 \mathrm{H}), 6.95(\mathrm{~m}, 1 \mathrm{H}), 7.10(\mathrm{~m}, 4 \mathrm{H}), 7.38(\mathrm{~m}, 2 \mathrm{H}) .{ }^{13} \mathrm{C} \mathrm{NMR}$ $\left(126 \mathrm{MHz}, \mathrm{CDCl}_{3}\right): \delta 20.6,36.9,72.7,78.4,84.1,115.3,115.9$ $(\mathrm{d}, J=21.8 \mathrm{~Hz}), 117.7,127.4,127.5,128.6,130.4(\mathrm{~d}, J=3.1$ $\mathrm{Hz}) ; 130.6,132.4,151.7,161.7$, 164.2. IR (ATR): 2920, 1603, 1554, 1513, 829, $751 \mathrm{~cm}^{-1}$. HPLC: (Lux i-Cellulose-5, nhexane/isopropanol $=90: 10,1.0 \mathrm{~mL} / \mathrm{min}, \lambda=210 \mathrm{~nm}) t_{\mathrm{R}}=$ $12.5 \min$ (major, $2 S, 3 S, 4 S$ ), $t_{\mathrm{R}}=15.5 \mathrm{~min}$ (minor, $2 R, 3 R, 4 R$ ). (dr 80:20; er 88:12).
(2S,3R,4S)-2-(4-Fluorophenyl)-6-methyl-3-nitro-4(nitromethyl)chromane (epi-3bb). Obtained as a minor diastereomer in the reaction of trans-4-fluoro- $\beta$-nitrostyrene, catalyst sq-4, and (E)-4-methyl-2-(2-nitrovinyl)phenol $\mathbf{1 b} .{ }^{1} \mathrm{H}$ NMR (500 MHz, $\left.\mathrm{CDCl}_{3}\right): \delta 2.30(\mathrm{~s}, 3 \mathrm{H}), 4.25(\mathrm{~m}, 1 \mathrm{H}), 4.90$ $\left(\mathrm{dd}, J_{1}=14.6 \mathrm{~Hz}, J_{2}=5.8 \mathrm{~Hz}, 1 \mathrm{H}\right), 5.01\left(\mathrm{dd}, J_{1}=14.6 \mathrm{~Hz}, J_{2}=\right.$ $7.6 \mathrm{~Hz}, 1 \mathrm{H}), 5.21\left(\mathrm{dd}, J_{1}=7.3 \mathrm{~Hz}, J_{2}=4.7 \mathrm{~Hz}, 1 \mathrm{H}\right), 5.63$ (d, $J$ $=7.3 \mathrm{~Hz}, 1 \mathrm{H}), 6.91(\mathrm{~m}, 2 \mathrm{H}), 7.09(\mathrm{~m}, 3 \mathrm{H}), 7.36(\mathrm{~m}, 2 \mathrm{H}) .{ }^{13} \mathrm{C}$ NMR (126 MHz, $\left.\mathrm{CDCl}_{3}\right): \delta 20.6,34.9,74.8,75.7,84.7,116.2$ $(\mathrm{d}, J=21.9 \mathrm{~Hz}), 116.6,117.3,124.5,127.6,128.4(\mathrm{~d}, J=8.4$ $\mathrm{Hz}$ ), 128.8, 131.0, 132.2, 150.2. HRMS (ESI-QTOF) $\mathrm{m} / z$ : calcd for $\mathrm{C}_{17} \mathrm{H}_{15} \mathrm{FN}_{2} \mathrm{O}_{5}+\mathrm{Na}, 369.0863$; found, 369.0861. IR (ATR): 1605, 1556, 1497, 819, 751, $694 \mathrm{~cm}^{-1}$. HPLC: (Lux iCellulose-5, $n$-hexane/isopropanol $=90: 10,1.0 \mathrm{~mL} / \mathrm{min}, \lambda=$ $210 \mathrm{~nm}$ ) $t_{\mathrm{R}}=21.7 \mathrm{~min}$ (major, $2 S, 3 R, 4 S$ ), $t_{\mathrm{R}}=60.7 \mathrm{~min}$ (minor, $2 R, 3 S, 4 R)$. (er $>99:<1)$.

(2S,3S, 4S)-2-(4-Chlorophenyl)-6-methyl-3-nitro-4(nitromethyl)chromane (3bc). Obtained as a major diastereomer in the reaction of trans-4-chloro- $\beta$-nitrostyrene $(73 \mathrm{mg}$, $0.4 \mathrm{mmol}, 2$ equiv), catalyst sq-4 $(5 \mathrm{mg}, 0.01 \mathrm{mmol}, 0.05$ equiv), and (E)-4-methyl-2-(2-nitrovinyl)phenol $\mathbf{1 b}(36 \mathrm{mg}$, $0.2 \mathrm{mmol}, 1$ equiv) to yield compound $3 \mathrm{bc}$ (62 $\mathrm{mg}, 0.17$ mmol, 85\%). Yellow solid. mp $137-139{ }^{\circ} \mathrm{C}$. $[\alpha]_{\mathrm{D}}^{23}+154.1(c$ 1.0, $\mathrm{CH}_{2} \mathrm{Cl}_{2}$ ). ${ }^{1} \mathrm{H}$ NMR (500 $\left.\mathrm{MHz}, \mathrm{CDCl}_{3}\right): \delta 2.34$ (s, 3H), $4.21(\mathrm{~m}, 1 \mathrm{H}), 4.5\left(\mathrm{dd}, J_{1}=13.5 \mathrm{~Hz}, J_{2}=10.5 \mathrm{~Hz}, 1 \mathrm{H}\right), 4.91$ $\left(\mathrm{dd}, J_{1}=13.5 \mathrm{~Hz}, J_{2}=4.0 \mathrm{~Hz}, 1 \mathrm{H}\right), 5.17(\mathrm{t}, J=2.1 \mathrm{~Hz}, 1 \mathrm{H})$, $.29(\mathrm{~d}, J=2.4 \mathrm{~Hz}, 1 \mathrm{H}), 6.96(\mathrm{~d}, J=8.4 \mathrm{~Hz}, 1 \mathrm{H}), 7.07(\mathrm{~m}, 1 \mathrm{H})$, $7.12(\mathrm{~m}, 1 \mathrm{H}), 7.36(\mathrm{~m}, 2 \mathrm{H}), 7.41(\mathrm{~m}, 2 \mathrm{H}) .{ }^{13} \mathrm{C} \mathrm{NMR}(126$ $\left.\mathrm{MHz}, \mathrm{CDCl}_{3}\right): \delta 20.6,37.0,72.7,78.4,83.9,115.3,117.8$, $127.0,128.6,129.1,130.7,132.5,133.1,135.1,151.6$. IR (ATR): $1554,1493,812,690,515 \mathrm{~cm}^{-1}$. HRMS (ESI-QTOF) $m / z$ : calcd for $\mathrm{C}_{17} \mathrm{H}_{15} \mathrm{ClN}_{2} \mathrm{O}_{5}+\mathrm{Na}, 385.0597$; found, 385.0562. HPLC: (Lux i-Cellulose-5, $n$-hexane/isopropanol $=$ $90: 10,1.0 \mathrm{~mL} / \mathrm{min}, \lambda=210 \mathrm{~nm}$ ) $t_{\mathrm{R}}=13.9 \mathrm{~min}$ (major, $2 S, 3 S, 4 S), t_{\mathrm{R}}=19.7 \mathrm{~min}$ (minor, $2 R, 3 R, 4 R$ ). (dr 68:32; er 95:5).

(2S,3R,4S)-2-(4-Chlorophenyl)-6-methyl-3-nitro-4(nitromethyl)chromane (epi-3bc). Obtained as a minor diastereomer in the reaction of trans-4-chloro- $\beta$-nitrostyrene, catalyst sq-4, and (E)-4-methyl-2-(2-nitrovinyl)phenol 1b. ${ }^{1} \mathrm{H}$ NMR (500 MHz, $\left.\mathrm{CDCl}_{3}\right): \delta 2.30(\mathrm{~s}, 3 \mathrm{H}), 4.22(\mathrm{~m}, 1 \mathrm{H}), 4.91$ $\left(\mathrm{dd}, J_{1}=14.6 \mathrm{~Hz}, J_{2}=5.8 \mathrm{~Hz}, 1 \mathrm{H}\right), 5.00\left(\mathrm{dd}, J_{1}=14.6 \mathrm{~Hz}, J_{2}=\right.$ $7.6 \mathrm{~Hz}, 1 \mathrm{H}), 5.21\left(\mathrm{dd}, J_{1}=7.0 \mathrm{~Hz}, J_{2}=4.6 \mathrm{~Hz}, 1 \mathrm{H}\right), 5.65(\mathrm{~d}, J$ $=7.0 \mathrm{~Hz}, 1 \mathrm{H}), 6.92(\mathrm{~d}, J=8.4 \mathrm{~Hz}, 1 \mathrm{H}), 7.32-7.37(\mathrm{~m}, 6 \mathrm{H})$. ${ }^{13} \mathrm{C} \mathrm{NMR}\left(126 \mathrm{MHz}, \mathrm{CDCl}_{3}\right): \delta 20.6,34.7,74.8,75.6,84.5$, $116.6,117.3,127.5,127.8,129.4,131.0,132.2,134.1,135.6$, 150.1. HRMS (ESI-QTOF) $m / z$ : calcd for $\mathrm{C}_{17} \mathrm{H}_{15} \mathrm{ClN}_{2} \mathrm{O}_{5}+$ $\mathrm{Na}, 385.0597$; found, 385.0562. IR (ATR): 1554, 1497, 817, 754, $696 \mathrm{~cm}^{-1}$. HPLC: (Lux i-Cellulose-5, $n$-hexane/ isopropanol $=90: 10,1.0 \mathrm{~mL} / \mathrm{min}, \lambda=210 \mathrm{~nm}) t_{\mathrm{R}}=25.5$ $\min$ (major, $2 S, 3 R, 4 S$ ), $t_{\mathrm{R}}=64.7 \mathrm{~min}$ (minor, $2 R, 3 S, 4 R$ ). (er 97:3).

(2S, 3S, 4S)-6-Methyl-2-(naphthalen-2-yl)-3-nitro-4(nitromethyl)chromane (3be). Obtained as a major diastereomer in the reaction of (E)-2-(2-nitroethenyl)-naphthalene ${ }^{38}$ $(80 \mathrm{mg}, 0.4 \mathrm{mmol}, 2$ equiv), catalyst sq-4 $(5 \mathrm{mg}, 0.01 \mathrm{mmol}$, 0.05 equiv), and (E)-4-methyl-2-(2-nitrovinyl)phenol $\mathbf{1 b}$ (36 $\mathrm{mg}, 0.2 \mathrm{mmol}, 1$ equiv) to yield compound $3 \mathrm{be}(48 \mathrm{mg}, 0.13$ mmol, 64\%). Yellow solid. mp 98-100 ${ }^{\circ} \mathrm{C}$. $[\alpha]_{\mathrm{D}}^{23}+126.7(c 1.0$, $\mathrm{CH}_{2} \mathrm{Cl}_{2}$ ). ${ }^{1} \mathrm{H} \mathrm{NMR}\left(500 \mathrm{MHz}, \mathrm{CDCl}_{3}\right): \delta 2.36(\mathrm{~s}, 3 \mathrm{H}), 4.26$ $(\mathrm{m}, 1 \mathrm{H}), 81(\mathrm{~m}, 1 \mathrm{H}), 4.95\left(\mathrm{dd}, J_{1}=13.4 \mathrm{~Hz}, J_{2}=4.1 \mathrm{~Hz}, 1 \mathrm{H}\right)$, $5.31(\mathrm{~m}, 1 \mathrm{H}), 5.48(\mathrm{~d}, J=2.3 \mathrm{~Hz}, 1 \mathrm{H}), 7.05(\mathrm{~m}, 1 \mathrm{H}), 7.09(\mathrm{~m}$, $1 \mathrm{H}), 7.14(\mathrm{~m}, 1 \mathrm{H}), 7.45(\mathrm{~d}, J=1.6 \mathrm{~Hz}, 1 \mathrm{H}), 7.53(\mathrm{~m}, 2 \mathrm{H})$, 
7.86-7.94 (m, 4H). ${ }^{13} \mathrm{C}$ NMR (126 MHz, $\left.\mathrm{CDCl}_{3}\right): \delta$ 20.7, $37.1,73.4,78.6,84.0,115.5,117.8,122.6,125.2,126.6,126.7$, $127.8,128.7,128.8,130.6,131.9,132.3,133.1,133.5,151.9$. IR (ATR): 2924, 1603, 1550, $812 \mathrm{~cm}^{-1}$. HPLC: (Lux i-Cellulose5 , $n$-hexane/isopropanol $=90: 10,1.0 \mathrm{~mL} / \mathrm{min}, \lambda=210 \mathrm{~nm}) t_{\mathrm{R}}$ $=18.7 \mathrm{~min}$ (major, 2S,3S,4S), $t_{\mathrm{R}}=28.4 \mathrm{~min}$ (minor, $2 R, 3 R, 4 R)$. (dr 62:38; er 88:12).

(2S,3S,4S)-6-Bromo-3-nitro-4-(nitromethyl)-2-phenylchromane $(3 \mathrm{ca})$. Obtained as a major diastereomer in the reaction of trans- $\beta$-nitrostyrene ( $60 \mathrm{mg}, 0.4 \mathrm{mmol}, 2$ equiv), catalyst sq4 (5 mg, $0.01 \mathrm{mmol}, 0.05$ equiv), and (E)-4-bromo-2-(2nitrovinyl)phenol 1c (49 mg, $0.2 \mathrm{mmol}, 1$ equiv) to yield compound $3 \mathrm{ca}(58 \mathrm{mg}, 0.15 \mathrm{mmol}, 74 \%)$. Yellow solid. $\mathrm{mp}$ 93-96 ${ }^{\circ} \mathrm{C} .[\alpha]_{\mathrm{D}}^{23}+109.6\left(c\right.$ 1.0, $\left.\mathrm{CH}_{2} \mathrm{Cl}_{2}\right) .{ }^{1} \mathrm{H}$ NMR (500 MHz, $\left.\mathrm{CDCl}_{3}\right): \delta 4.23(\mathrm{~m}, 1 \mathrm{H}), 4.76\left(\mathrm{dd}, J_{1}=13.7 \mathrm{~Hz}, J_{2}=10.4 \mathrm{~Hz}\right.$, $1 \mathrm{H}), 4.89\left(\mathrm{dd}, J_{1}=13.7 \mathrm{~Hz}, J_{2}=4.1 \mathrm{~Hz}, 1 \mathrm{H}\right), 5.19(\mathrm{~m}, 1 \mathrm{H})$, $5.32(\mathrm{~d}, J=2.5 \mathrm{~Hz}, 1 \mathrm{H}), 6.98(\mathrm{~d}, J=9.4 \mathrm{~Hz}, 1 \mathrm{H}), 7.38-7.45$ $(\mathrm{m}, 7 \mathrm{H}) .{ }^{13} \mathrm{C}$ NMR $\left(126 \mathrm{MHz}, \mathrm{CDCl}_{3}\right): \delta 36.7,73.4,78.1$, 83.6, 114.8, 117.9, 119.8, 125.5, 129.0, 129.4, 131.1, 132.9, 133.9, 153.1. IR (ATR): 1550, 1481, $816 \mathrm{~cm}^{-1}$. HRMS (ESIQTOF) $m / z$ : calcd for $\mathrm{C}_{16} \mathrm{H}_{13} \mathrm{BrN}_{2} \mathrm{O}_{5}+\mathrm{Na}$, 414.9897; found, 414.9904. HPLC: (Lux i-Cellulose-5, $n$-hexane/isopropanol = 90:10, $1.0 \mathrm{~mL} / \mathrm{min}, \lambda=210 \mathrm{~nm}$ ) $t_{\mathrm{R}}=18.7 \mathrm{~min}$ (major, $2 S, 3 S, 4 S), t_{\mathrm{R}}=21.7 \min$ (minor, $2 R, 3 R, 4 R$ ). (dr 79:21; er $96: 4)$.

(2S,3S,4S)-6-Bromo-2-(4-fluorophenyl)-3-nitro-4(nitromethyl)chromane (3cb). Obtained as a major diastereomer in the reaction of trans-4-fluoro- $\beta$-nitrostyrene $(67 \mathrm{mg}$, $0.4 \mathrm{mmol}, 2$ equiv), catalyst sq-4 $(5 \mathrm{mg}, 0.01 \mathrm{mmol}, 0.05$ equiv), and (E)-4-bromo-2-(2-nitrovinyl)phenol 1c (49 mg, $0.2 \mathrm{mmol}, 1$ equiv) to yield compound $3 \mathrm{cb}(68 \mathrm{mg}, 0.17$ mmol, 83\%). Yellow solid. mp $138-141{ }^{\circ} \mathrm{C}$. $[\alpha]_{\mathrm{D}}^{23}+112.5(c$ 1.0, $\left.\mathrm{CH}_{2} \mathrm{Cl}_{2}\right) .{ }^{1} \mathrm{H} \mathrm{NMR}\left(500 \mathrm{MHz},\left(\mathrm{CD}_{3}\right)_{2} \mathrm{CO}\right): \delta 4.50\left(\mathrm{dd}, J_{1}\right.$ $\left.=10.1 \mathrm{~Hz}, J_{2}=3.6,1 \mathrm{H}\right), 5.22\left(\mathrm{dd}, J_{1}=15.9 \mathrm{~Hz}, J_{2}=3.6 \mathrm{~Hz}\right.$, $1 \mathrm{H}), 5.32\left(\mathrm{dd}, J_{1}=16.0 \mathrm{~Hz}, J_{2}=10.2 \mathrm{~Hz}, 1 \mathrm{H}\right), 5.69\left(\mathrm{dd}, J_{1}=\right.$ $\left.2.4 \mathrm{~Hz}, J_{2}=1.0 \mathrm{~Hz}, 1 \mathrm{H}\right), 5.81(\mathrm{~d}, J=2.4 \mathrm{~Hz}, 1 \mathrm{H}), 7.04(\mathrm{~d}, J=$ $8.7 \mathrm{~Hz}, 1 \mathrm{H}), 7.22(\mathrm{~m}, 2 \mathrm{H}), 7.47(\mathrm{~m}, 1 \mathrm{H}), 7.63(\mathrm{~m}, 2 \mathrm{H}), 7.83$ $(\mathrm{m}, 1 \mathrm{H}) .{ }^{13} \mathrm{C}$ NMR $\left(126 \mathrm{MHz},\left(\mathrm{CD}_{3}\right)_{2} \mathrm{CO}\right): \delta 36.1,72.4,76.8$, $84.7,113.7,115.3(\mathrm{~d}, J=21.9 \mathrm{~Hz}), 119.2,120.0,128.1(\mathrm{~d}, J=$ $8.5 \mathrm{~Hz}$ ), 131.6, 131.7, 131.8, 132.1, 153.6, 161.8 (d, $J=245.5$ $\mathrm{Hz})$. IR (ATR): 2920, 1550, 1513, 816, $661 \mathrm{~cm}^{-1}$. HRMS (ESI-QTOF) $m / z$ : calcd for $\mathrm{C}_{16} \mathrm{H}_{12} \mathrm{BrFN}_{2} \mathrm{O}_{5}+\mathrm{Na}, 432.9797$; found, 432.9810. HPLC: (Lux i-Cellulose-5, $n$-hexane/ isopropanol $=90: 10,1.0 \mathrm{~mL} / \mathrm{min}, \lambda=210 \mathrm{~nm}) t_{\mathrm{R}}=15.2$ $\min ($ major, $2 S, 3 S, 4 S), t_{\mathrm{R}}=16.7$ min (minor, $\left.2 R, 3 R, 4 R\right)$. $(\mathrm{dr}$ $86: 14$; er $97: 3)$.

(2S,3S,4S)-6-Bromo-2-(4-chlorophenyl)-3-nitro-4(nitromethyl)chromane (3cc). Obtained according to general procedure, using trans-4-chloro- $\beta$-nitrostyrene $(0.4 \mathrm{mmol}, 73$ mg, 2 equiv), catalyst sq-4 ( $0.01 \mathrm{mmol}, 0.05$ equiv), and $(E)-4-$ bromo-2-(2-nitrovinyl)phenol compound 1c (49 mg, 0.2 mmol, 1 equiv) to yield compound $3 \mathrm{cc}(68 \mathrm{mg}, 0.16 \mathrm{mmol}$, 79\%). mp $226-228{ }^{\circ} \mathrm{C}$. $[\alpha]_{\mathrm{D}}^{23}+9.3\left(\right.$ c $\left.1.0, \mathrm{CHCl}_{3}\right) .{ }^{1} \mathrm{H} \mathrm{NMR}$ $\left(500 \mathrm{MHz},\left(\mathrm{CD}_{3}\right)_{2} \mathrm{CO}\right): \delta 4.50(\mathrm{~m}, 1 \mathrm{H}), 5.22\left(\mathrm{dd}, J_{1}=15.9\right.$ $\left.\mathrm{Hz}, J_{2}=3.6 \mathrm{~Hz}, 1 \mathrm{H}\right), 5.32\left(\mathrm{dd}, J_{1}=16.0 \mathrm{~Hz}, J_{2}=10.1 \mathrm{~Hz}, 1 \mathrm{H}\right)$, $5.71(\mathrm{~m}, 1 \mathrm{H}), 5.82(\mathrm{~d}, J=2.4,1 \mathrm{H}), 7.05(\mathrm{~d}, J=8.8 \mathrm{~Hz}, 1 \mathrm{H})$, 7.45-7.49 (m, 3H), $7.60(\mathrm{~m}, 2 \mathrm{H}), 7.82(\mathrm{~m}, 1 \mathrm{H}) .{ }^{13} \mathrm{C} \mathrm{NMR}$ $\left(126 \mathrm{MHz},\left(\mathrm{CD}_{3}\right)_{2} \mathrm{CO}\right): \delta 36.1,72.4,76.8\left(\underline{\mathrm{CH}_{2}}\right), 84.52$, $113.8,119.2,120.0,127.7,128.6,131.8,132.1,134.1,134.55$, 153.5. IR (ATR): 1697, 1550, 1481, 808, $641 \mathrm{~cm}^{-1}$. HRMS (ESI-QTOF) $m / z$ : calcd for $\mathrm{C}_{16} \mathrm{H}_{12} \mathrm{BrClN}_{2} \mathrm{O}_{5}+\mathrm{Na}$, 448.9497; found, 448.9516. HPLC: (Lux i-Cellulose-5, $n$-hexane/ isopropanol $=90: 10,1.0 \mathrm{~mL} / \mathrm{min}, \lambda=210 \mathrm{~nm}) t_{\mathrm{R}}=17.1$ $\min$ (major, $2 S, 3 S, 4 S), t_{\mathrm{R}}=19.7 \min ($ minor, $2 R, 3 R, 4 R)$. $(\mathrm{dr}$ $88: 12$; er 93:7).

(2S,3S,4S)-6-Bromo-2-(naphthalen-2-yl)-3-nitro-4(nitromethyl)chromane (3ce). Obtained as a major diastereomer in the reaction of (E)-2-(2-nitroethenyl)-naphthalene ${ }^{41}$ ( $80 \mathrm{mg}, 0.4 \mathrm{mmol}, 2$ equiv), catalyst sq-4 $(5 \mathrm{mg}, 0.01 \mathrm{mmol}$, 0.05 equiv), and (E)-4-bromo-2-(2-nitrovinyl)phenol 1c (49 $\mathrm{mg}, 0.2 \mathrm{mmol}, 1$ equiv) to yield compound $3 \mathrm{ce}(67 \mathrm{mg}, 0.15$ mmol, $76 \%$ ). Yellow solid. mp $129-131{ }^{\circ} \mathrm{C}$. $[\alpha]_{\mathrm{D}}^{23}+98.9(c 1.0$, $\mathrm{CH}_{2} \mathrm{Cl}_{2}$ ). ${ }^{1} \mathrm{H}$ NMR $\left(500 \mathrm{MHz},\left(\mathrm{CD}_{3}\right)_{2} \mathrm{CO}\right): \delta 4.54$ (dd, $J_{1}=$ $\left.10.2 \mathrm{~Hz}, J_{2}=3.6 \mathrm{~Hz}, 1 \mathrm{H}\right), 5.27\left(\mathrm{dd}, J_{1}=15.9 \mathrm{~Hz}, J_{2}=3.6 \mathrm{~Hz}\right.$, $1 \mathrm{H}), 5.40\left(\mathrm{dd}, J_{1}=15.9 \mathrm{~Hz}, J_{2}=10.2 \mathrm{~Hz}, 1 \mathrm{H}\right), 5.81(\mathrm{dd}, J=$ $2.5 \mathrm{~Hz}, 1.0 \mathrm{~Hz}, 1 \mathrm{H}), 5.97(\mathrm{~d}, J=1.4 \mathrm{~Hz}, 1 \mathrm{H}), 7.11(\mathrm{~d}, J=8.8$ $\mathrm{Hz}, 1 \mathrm{H}), 7.50\left(\mathrm{dd}, J_{1}=8.7 \mathrm{~Hz}, J_{2}=2.4 \mathrm{~Hz}, 1 \mathrm{H}\right), 7.56(\mathrm{~m}, 2 \mathrm{H})$, $7.71\left(\mathrm{dd}, J_{1}=8.6, J_{2}=1.8 \mathrm{~Hz}, 1 \mathrm{H}\right), 7.86(\mathrm{~d}, J=2.4 \mathrm{~Hz}, 1 \mathrm{H})$, 7.94-7.99 (m, 3H), $8.12(\mathrm{~s}, 1 \mathrm{H}) .{ }^{13} \mathrm{C}$ NMR (126 MHz, $\left.\left(\mathrm{CD}_{3}\right)_{2} \mathrm{CO}\right): \delta 36.2,73.1,76.9,84.7,113.7,119.3,120.2$, $123.4,125.1,126.5,126.6,127.7,128.1,128.2,131.8,132.1$, 133.0, 133.1, 133.5, 153.7. IR (ATR): 1697, 1550, 1481, 816, $747 \mathrm{~cm}^{-1}$. HRMS (ESI-QTOF) $m / z$ : calcd for $\mathrm{C}_{20} \mathrm{H}_{15} \mathrm{BrN}_{2} \mathrm{O}_{5}$ $+\mathrm{Na}$, 465.0099; found, 465.0068. HPLC: (Lux i-Cellulose-5, $n$-hexane/isopropanol $=90: 10,1.0 \mathrm{~mL} / \mathrm{min}, \lambda=210 \mathrm{~nm}) t_{\mathrm{R}}=$ $24.0 \mathrm{~min}$ (major, $2 S, 3 S, 4 S$ ), $t_{\mathrm{R}}=30.9 \mathrm{~min}$ (minor, $2 R, 3 R, 4 R$ ). (dr 78:22; er 88:12).

(2S,3S,4S)-6-Chloro-3-nitro-4-(nitromethyl)-2-phenylchromane (3da). Obtained as a major diastereomer in the reaction of trans- $\beta$-nitrostyrene $(60 \mathrm{mg}, 0.4 \mathrm{mmol}, 2$ equiv), catalyst sq4 (5 mg, $0.01 \mathrm{mmol}, 0.05$ equiv), and (E)-4-chloro-2-(2nitrovinyl)phenol 1d (40 mg, $0.2 \mathrm{mmol}, 1$ equiv) to yield compound 3da (45 mg, $0.13 \mathrm{mmol}, 65 \%$ ). Yellow solid. $\mathrm{mp}$ $71-73{ }^{\circ} \mathrm{C} .[\alpha]_{\mathrm{D}}^{23}+115.0\left(c 1.0, \mathrm{CH}_{2} \mathrm{Cl}_{2}\right) .{ }^{1} \mathrm{H}$ NMR $(500 \mathrm{MHz}$, $\left.\mathrm{CDCl}_{3}\right): \delta 4.23(\mathrm{~m}, 1 \mathrm{H}), 4.77(\mathrm{~m}, 1 \mathrm{H}), 4.89\left(\mathrm{dd}, J_{1}=13.7 \mathrm{~Hz}\right.$, $\left.J_{2}=4.0 \mathrm{~Hz}, 1 \mathrm{H}\right), 5.20\left(\mathrm{dd}, J_{1}=2.5 \mathrm{~Hz}, J_{2}=1.7 \mathrm{~Hz}, 1 \mathrm{H}\right), 5.32$ $(\mathrm{d}, J=2.4 \mathrm{~Hz}, 1 \mathrm{H}), 7.05(\mathrm{~d}, J=9.3 \mathrm{~Hz}, 1 \mathrm{H}), 7.06-7.46(\mathrm{~m}$, $7 \mathrm{H}) .{ }^{13} \mathrm{C} \mathrm{NMR}\left(126 \mathrm{MHz}, \mathrm{CDCl}_{3}\right): \delta 36.8,73.5,78.1,83.6$, $119.5,125.5,127.7,128.1,129.0,129.4,130.0,131.9,133.9$, 152.6. IR (ATR): 2924, 1550, 816, 755, $698 \mathrm{~cm}^{-1}$. HPLC: (Lux-i-Cellulose-5, $n$-hexane/isopropanol $=90: 10,1.0 \mathrm{~mL} /$ $\min , \lambda=210 \mathrm{~nm}) t_{\mathrm{R}}=16.8 \min ($ major, $2 S, 3 S, 4 S), t_{\mathrm{R}}=18.6$ $\min$ (minor, 2R,3R,4R). (dr 74:26; er 85:15).

(2S,3S,4S)-3-Methyl-3-nitro-4-(nitromethyl)-2-phenylchromane (3af). ${ }^{24}$ Obtained as a major diastereoisomer in the reaction of trans $\alpha$-methyl- $\beta$-nitrostyrene $(65 \mathrm{mg}, 0.4 \mathrm{mmol}, 2$ equiv), catalyst sq-6 ( $10 \mathrm{mg}, 0.02 \mathrm{mmol}, 0.10$ equiv), and 2-(2nitrovinyl)phenol 1a (33 mg, $0.2 \mathrm{mmol}, 1$ equiv) to yield the products ( $30 \mathrm{mg}, 0.1 \mathrm{mmol}, 50 \%$ ) as an inseparable mixture of 3af and epi-3af. ${ }^{1} \mathrm{H}$ NMR (500 MHz, $\left.\mathrm{CDCl}_{3}\right): \delta 7.41-7.29$ $(\mathrm{m}, 12 \mathrm{H}), 7.17-7.16(\mathrm{~m}, 1 \mathrm{H})$ (major), 7.07-6.98 (m, 5H), $5.75(\mathrm{~s}, 1 \mathrm{H})$ (major), 5.59 (s, 1H) (minor), 5.17 (dd, $J=8.1$ $\mathrm{Hz}, J=2.9 \mathrm{~Hz}, 1 \mathrm{H})$ (minor), $5.11(\mathrm{dd}, J=15.2 \mathrm{~Hz}, J=6.3 \mathrm{~Hz}$, $1 \mathrm{H}$ ) (major), 4.88 (dd, $J=15.2 \mathrm{~Hz}, J=5.6 \mathrm{~Hz}, 1 \mathrm{H}$ ) (major), $4.73(\mathrm{dd}, J=14.6 \mathrm{~Hz}, J=8.2 \mathrm{~Hz}, 1 \mathrm{H})$ (minor), 4.44 (dd, $J=$ $14.7 \mathrm{~Hz}, J=3.1 \mathrm{~Hz}, 1 \mathrm{H}$ ) (minor), $4.14(\mathrm{t}, J=5.9 \mathrm{~Hz}, 1 \mathrm{H}$ ) (major), $1.63(\mathrm{~s}, 3 \mathrm{H})$ (major), $1.40(\mathrm{~s}, 3 \mathrm{H})$ (minor). HPLC: (Lux i-Amylose-1, $n$-hexane/isopropanol $=97: 3,1.0 \mathrm{~mL} / \mathrm{min}$, $\lambda=210 \mathrm{~nm}$ ) $t_{\mathrm{R}}=14.5 \min$ (major, $2 S, 3 R, 4 S$ ), $t_{\mathrm{R}}=15.2$ (minor, $2 R, 3 S, 4 R$ ). (er 56:44), $t_{\mathrm{R}}=18.1 \mathrm{~min}$ (minor, $2 R, 3 R, 4 R$ ), $t_{\mathrm{R}}=20.0$ (major, $\left.2 S, 3 S, 4 S\right)$. (dr 56:44; er 77:23). 


\section{ASSOCIATED CONTENT}

\section{S Supporting Information}

The Supporting Information is available free of charge on the ACS Publications website at DOI: 10.1021/acsomega.8b02302.

${ }^{1} \mathrm{H}$ NMR and ${ }^{13} \mathrm{C}$ NMR spectra for new compounds, Xray crystallographic data for 3ac, copy of IR spectra for polymeric squaramide 9, and copies of the HPLC chromatograms (PDF)

\section{AUTHOR INFORMATION}

\section{Corresponding Authors}

*E-mail: jmandres@qo.uva.es (J.M.A.).

*E-mail: pedrosa@qo.uva.es (R.P.).

\section{ORCID}

Rafael Pedrosa: 0000-0002-3652-7301

\section{Notes}

The authors declare no competing financial interest.

\section{ACKNOWLEDGMENTS}

The authors thank the Ministerio de Economía of Spain (Project FEDER-CTQ2014-59870-P) and Junta de Castilla y León (Projects FEDER-VA115P17 and VA149G18) for financial support. The aid in the X-ray diffraction determinations provided by Prof. J. A. Miguel is also acknowledged.

\section{REFERENCES}

(1) Shen, H. C. Asymmetric synthesis of chiral chromans. Tetrahedron 2009, 65, 3931.

(2) Harel, D.; Schepmann, D.; Prinz, H.; Brun, R.; Schmidt, T. J.; Wünsch, B. Natural Product Derived Antiprotozoal Agents: Synthesis, Biological Evaluation, and Structure-Activity Relationships of Novel Chromene and Chromane Derivatives. J. Med. Chem. 2013, 56, 7442.

(3) Starks, C. M.; Williams, R. B.; Norman, V. L.; Rice, S. M.; O'Neil-Johnson, M.; Lawrence, J. A.; Eldridge, G. R. Antibacterial chromene and chromane stilbenoids from Hymenocardia acida. Phytochemistry 2014, 98, 216.

(4) Khan, S.; Shukla, S.; Sinha, S.; Lakra, A. D.; Bora, H. K.; Meeran, S. M. Centchroman suppresses breast cancer metastasis by reversing epithelial-mesenchymal transition via downregulation of HER2/ ERK1/2/MMP-9 signaling. Int. J. Biochem. Cell Biol. 2015, 58, 1.

(5) Fridén-Saxin, M.; Seifert, T.; Malo, M.; da Silva Andersson, K.; Pemberton, N.; Dyrager, C.; Friberg, A.; Dahlén, K.; Wallén, E. A. A.; Grøtli, M.; Luthman, K. Chroman-4-one and chromone based somatostatin $\beta$-turn mimetics. Eur. J. Med. Chem. 2016, 114, 59.

(6) Masesane, I. B.; Desta, Z. Y. Reactions of salicylaldehyde and enolates or their equivalents: versatile synthetic routes to chromane derivatives. Beilstein J. Org. Chem. 2012, 8, 2166.

(7) Hou, W.; Zheng, B.; Chen, J.; Peng, Y. Asymmetric Synthesis of Polysubstituted 4-Amino- and 3,4-Diaminochromanes with a Chiral Multifunctional Organocatalyst. Org. Lett. 2012, 14, 2378.

(8) Bhanja, C.; Jena, S.; Nayak, S.; Mohapatra, S. Organocatalytic tandem Michael addition reactions: A powerful access to the enantioselective synthesis of functionalized chromenes, thiochromenes and 1,2-dihydroquinolines. Beilstein J. Org. Chem. 2012, 8, 1668.

(9) Yang, W.; Yang, Y.; Du, D.-M. Squaramide-Tertiary Amine Catalyzed Asymmetric Cascade Sulfa-Michael/Michael Addition via Dynamic Kinetic Resolution: Access to Highly Functionalized Chromans with Three Contiguous Stereocenters. Org. Lett. 2013, 15, 1190.

(10) Bai, W.-J.; David, J. G.; Feng, Z.-G.; Weaver, M. G.; Wu, K.-L.; Pettus, T. R. R. The Domestication of ortho-Quinone Methides. Acc. Chem. Res. 2014, 47, 3655.
(11) Netscher, T. Building up quarternary stereocenters of chromans by asymmetric redox organocatalysis: a new entry to vitamin E. Angew. Chem., Int. Ed. 2014, 53, 14313.

(12) Zheng, B.; Hou, W.; Peng, Y. Asymmetric oxa-Michael-azaHenry Cascade Reaction of 2-Hydroxyaryl-Substituted $\alpha$-Amido Sulfones and Nitroolefins Mediated by Chiral Squaramides. ChemCatChem 2014, 6, 2527.

(13) Majumdar, N.; Paul, N. D.; Mandal, S.; de Bruin, B.; Wulff, W. D. Catalytic Synthesis of 2H-Chromenes. ACS Catal. 2015, 5, 2329.

(14) $\mathrm{Hu}, \mathrm{N}$. ; Li, K.; Wang, Z.; Tang, W. Synthesis of Chiral 1,4Benzodioxanes and Chromans by Enantioselective PalladiumCatalyzed Alkene Aryloxyarylation Reactions. Angew. Chem., Int. Ed. 2016, 55, 5044

(15) Mao, H.; Lin, A.; Tang, Y.; Shi, Y.; Hu, H.; Cheng, Y.; Zhu, C. Organocatalytic oxa/aza-Michael-Michael Cascade Strategy for the Construction of Spiro [Chroman/Tetrahydroquinoline-3,3'-oxindole] Scaffolds. Org. Lett. 2013, 15, 4062.

(16) Zheng, W.; Zhang, J.; Liu, S.; Yu, C.; Miao, Z. Asymmetric synthesis of spiro[chroman-3,3'-pyrazol] scaffolds with an all-carbon quaternary stereocenter via a oxa-Michael-Michael cascade strategy with bifunctional amine-thiourea organocatalysts. RSC $A d v$. 2015, 5, 91108.

(17) Zhao, K.; Zhi, Y.; Shu, T.; Valkonen, A.; Rissanen, K.; Enders, D. Organocatalytic Domino Oxa-Michael/1,6-Addition Reactions: Asymmetric Synthesis of Chromans Bearing Oxindole Scaffolds. Angew. Chem., Int. Ed. 2016, 55, 12104.

(18) Zhu, Y.; Li, X.; Chen, Q.; Su, J.; Jia, F.; Qiu, S.; Ma, M.; Sun, Q.; Yan, W.; Wang, K.; Wang, R. Highly Enantioselective Cascade Reaction Catalyzed by Squaramides: the Synthesis of $\mathrm{CF}_{3}$-Containing Chromanes. Org. Lett. 2015, 17, 3826.

(19) Saha, P.; Biswas, A.; Molleti, N.; Singh, V. K. Enantioselective Synthesis of Highly Substituted Chromans via the Oxa-MichaelMichael Cascade Reaction with a Bifunctional Organocatalyst. J. Org. Chem. 2015, 80, 11115.

(20) Wang, X.-F.; An, J.; Zhang, X.-X.; Tan, F.; Chen, J.-R.; Xiao, W.-J. Catalytic Asymmetric Aza-Michael-Michael Addition Cascade: Enantioselective Synthesis of Polysubstituted 4-Aminobenzopyrans. Org. Lett. 2011, 13, 808.

(21) Jia, Z.-X.; Luo, Y.-C.; Cheng, X.-N.; Xu, P.-F.; Gu, Y.-C. Organocatalyzed Michael-Michael Cascade Reaction: Asymmetric Synthesis of Polysubstituted Chromans. J. Org. Chem. 2013, 78, 6488.

(22) Wang, X.-F.; Hua, Q.-L.; Cheng, Y.; An, X.-L.; Yang, Q.-Q.; Chen, J.-R.; Xiao, W.-J. Organocatalytic Asymmetric Sulfa-Michael/ Michael Addition Reactions: A Strategy for the Synthesis of Highly Substituted Chromans with a Quaternary Stereocenter. Angew. Chem., Int. Ed. 2010, 49, 8379.

(23) Yao, C.-F.; Jang, Y.-J.; Yan, M.-C. An easy and efficient synthesis of 3-nitrochromans. Tetrahedron Lett. 2003, 44, 3813.

(24) Tang, C.-K.; Feng, K.-X.; Xia, A.-B.; Li, C.; Zheng, Y.-Y.; Xu, Z.-Y.; Xu, D.-Q. Asymmetric synthesis of polysubstituted chiral chromans via an organocatalytic oxa-Michael-nitro-Michael domino reaction. RSC Adv. 2018, 8, 3095.

(25) Gruttadauria, M.; Giacalone, F.; Noto, R. Supported proline and proline-derivatives as recyclable organocatalysts. Chem. Soc. Rev. 2008, 37, 1666

(26) Kristensen, T. E.; Hansen, T. Polymer-Supported Chiral Organocatalysts: Synthetic Strategies for the Road Towards Affordable Polymeric Immobilization. Eur. J. Org. Chem. 2010, 2010,3179

(27) Itsuno, S.; Hassan, M. M. Polymer-immobilized chiral catalysts. RSC Adv. 2014, 4, 52023.

(28) Altava, B.; Burguete, M. I.; García-Verdugo, E.; Luis, S. V. Chiral catalysts immobilized on achiral polymers: effect of the polymer support on the performance of the catalyst. Chem. Soc. Rev. 2018, 47, 2722.

(29) Tsubogo, T.; Ishiwata, T.; Kobayashi, S. Asymmetric CarbonCarbon Bond Formation under Continuous-Flow Conditions with Chiral Heterogeneous Catalysts. Angew. Chem., Int. Ed. 2013, 52, 6590. 
(30) Puglisi, A.; Benaglia, M.; Chiroli, V. Stereoselective organic reactions promoted by immobilized chiral catalysts in continuous flow systems. Green Chem. 2013, 15, 1790.

(31) Zhao, D.; Ding, K. Recent Advances in Asymmetric Catalysis in Flow. ACS Catal. 2013, 3, 928.

(32) Munirathinam, R.; Huskens, J.; Verboom, W. Supported Catalysis in Continuous-Flow Microreactors. Adv. Synth. Catal. 2015, $357,1093$.

(33) Andrés, J. M.; Maestro, A.; Valle, M.; Pedrosa, R. Chiral Bifunctional Thioureas and Squaramides and Their Copolymers as Recoverable Organocatalysts. Stereoselective Synthesis of 2-Substituted 4-Amino-3-nitrobenzopyrans and 3-Functionalized 3,4Diamino-4H-Chromenes. J. Org. Chem. 2018, 83, 5546.

(34) Korotaev, V. Y.; Kotovich, I. V.; Barkov, A. Y.; Kutyashev, I. B.; Kodess, M. I.; Sosnovskikh, V. Y. Uncatalyzed, highly stereoselective addition of $\alpha$-morpholinostyrene to 3-nitro-2-(trihalomethyl)-2 H -chromenes. Synthesis of trans - cis - and trans - trans -3-nitro-4phenacyl-(2-trihalomethyl)chromanes. Tetrahedron 2016, 72, 216.

(35) CCDC 1858605 contains the crystallographic data for compound ent-8a. These data can be obtained free of charge from the Cambridge Crystallographic Data Center via www.ccdc.cam.ac. uk/data request/cif.

(36) Pedrosa, R.; Manzano, R.; Andrés, J. M. Direct Experimental Evidence for the Epimerization of Diastereoisomers in the Enantioselective Organocatalyzed Michael Addition of Acetoacetates to Nitroolefins. Synlett 2011, 2203.

(37) Hoveyda, H. R.; Marsault, E.; Gagnon, R.; Mathieu, A. P.; Vézina, M.; Landry, A.; Wang, Z.; Benakli, K.; Beaubien, S.; SaintLouis, C.; Brassard, M.; Pinault, J.-F.; Ouellet, L.; Bhat, S.; Ramaseshan, M.; Peng, X.; Foucher, L.; Beauchemin, S.; Bhérer, P.; Veber, D. F.; Peterson, M. L.; Fraser, G. L. Optimization of the Potency and Pharmacokinetic Properties of a Macrocyclic Ghrelin Receptor Agonist (Part I): Development of Ulimorelin (TZP-101) from Hit to Clinic. J. Med. Chem. 2011, 54, 8305.

(38) Huang, P.; Li, Y.; Fu, X.; Zhang, R.; Jin, K.; Wang, W.; Duan, C. Silver(I)-catalyzed denitrative trifluoromethylation of $\beta$-nitrostyrenes with $\mathrm{CF} 3 \mathrm{SO}_{2} \mathrm{Na}$. Tetrahedron Lett. 2016, 57, 4705.

(39) Shen, Y.; Lai, X.; Zha, G.; Liu, W.; Xu, Y.; Sun, P.; Xia, T.; Shen, Y. Enantioselective Michael Addition of Pyrazolin-5-ones to $\beta$ $\mathrm{CF}_{3}-\beta$ - Disubstituted Nitroalkenes Catalyzed by Squaramide Organocatalyst. Synlett 2016, 27, 1983.

(40) Opalka, S. M.; Steinbacher, J. L.; Lambiris, B. A.; McQuade, D. T. Thiourea/Proline Derivative-Catalyzed Synthesis of Tetrahydrofuran Derivatives: A Mechanistic View. J. Org. Chem. 2011, 76, 6503. 